Review

\title{
Experimental Characterization Protocols for Wear Products from Disc Brake Materials
}

\author{
Ankur Sinha *D, Gloria Ischia, Cinzia Menapace $\mathbb{D}$ and Stefano Gialanella \\ Department of Industrial Engineering, University of Trento, Via Sommarive 9, 38123 Trento, Italy; \\ gloria.ischia@unitn.it (G.I.); cinzia.menapace@unitn.it (C.M.); stefano.gialanella@unitn.it (S.G.) \\ * Correspondence: ankur.sinha@unitn.it; Tel.: +39-0461-282420
}

Received: 23 September 2020; Accepted: 13 October 2020; Published: 15 October 2020

\begin{abstract}
The increasing interest in the emission from the disc brake system poses new challenges for the characterization approaches used to investigate the particles emitted from the wearing out of the relevant tribological systems. This interest stems from different factors. In the first place, a thorough characterization of brake wear particles is important for a complete understanding of the active tribological mechanisms, under different testing and servicing conditions. This information is an important prerequisite not only for the general improvement of brake systems, but also to guide the development of new materials for discs and brake pads, responding better to the specific requirements, including not only performance, but also the emission behavior. In this review paper, the main material characterization protocols used for the analyses of the brake wear products, with particular regard for the airborne fraction, are presented. Reliable results require investigating the fine and ultrafine particles as concerns their composition together with their structural and microstructural aspects. For this reason, in general, multi-analytical protocols are very much recommended.
\end{abstract}

Keywords: brake pad; particulate matter; wear debris characterization

\section{Introduction}

In the year 2017, air pollution was linked with the deaths of about 4.9 million people worldwide, and particulate matter (PM) was considered a key component of the ambient air pollution [1]. The airborne PM has a wide range of sources and correspondingly a large variation in size and composition. Studies have concluded that many anthropogenic emissions are responsible for its presence in the environment, even at a hazardous level, like vehicular road traffic (exhaust and non-exhaust), construction and demolition of buildings, power plants, smoking, aircraft and ships, and cooking. [2,3]. PM posing health risks [4,5] can be ranked according to their average aerodynamic diameter, $\mathrm{D}: \mathrm{D}<0.1 \mu \mathrm{m}$ are ultrafine particles, $\mathrm{PM}_{0.1} ; 0.1 \mu \mathrm{m}<\mathrm{D}<2.5 \mu \mathrm{m}$ pertain to fine particles, $\mathrm{PM}_{2.5} ; 2.5 \mu \mathrm{m}<\mathrm{D}<10 \mu \mathrm{m}$ are coarse particles, $\mathrm{PM}_{10}$.

Road traffic is regarded as one of the main source of PM in urban areas, with contributions from both exhaust (gaseous species from complete and incomplete fuel combustion, lubricant volatilization during combustion [6]) as well as non-exhaust emissions [7,8]. These latter include the wearing out of brakes, tires, clutch plates and road surfaces, vehicle body through corrosion [9], and erosion of the active layer of catalytic converter [10]. With the advancements in technology, and because of stringent measures undertaken by the government bodies, significant emission reductions have been attained from the tailpipe exhaust [11,12]. Many researchers have shown that both exhaust and non-exhaust emissions contribute almost equally to the increment in airborne PM [11-14]. At the present time, non-exhaust emissions are not regulated. Nonetheless, their relative amount is expected to rise with time, considering that exhaust emissions are drastically reduced or fully eliminated in the case of hybrid and electrical vehicles, respectively [15]. In this regard, it is to be expected that electrical vehicles 
will produce more non-exhaust emissions than conventional ones, especially if they are provided with heavy batteries for greater driving ranges [16].

As concerns a disc brake setup, it essentially incorporates two pads and a rotating disc, which serve to stop a vehicle in a minimum possible distance after its application. Debris produced during as well as after the sliding contact between the disc and pad consists of fragments of different size and mass, depending on the actual density [17-20]. In the U.S., the hazardous materials used in brake pads are monitored and controlled by the legislation, while in Europe, the focus of the legislation is on the overall PM [21]. More than several thousand metric tons of brake wear debris are released by millions of vehicles on the road each year worldwide. The raw materials used in the brake systems are subjected to complex thermo-mechanical-chemical interactions occurring during the braking process, often changing the original material composition. The size of generated particles is also important, as depending on the size, particles can be released in the atmosphere as airborne PM; can be deposited onto the brake system hardware; can fall on the roadside environment [22]. In addition to these particles, the thermal decomposition of the brake constituents releases volatiles in the atmosphere [23-25]. The primary reasons for studying wear particles originating from disc brake systems are harmful health effects and the need to abide by the limits set by the regulating agencies. Additionally, aesthetic effects due to soiling of the brake component surfaces can be considered as a secondary reason [26].

Considering the variety of material compositions used for brake systems, large variations in the results have been reported from studies conducted on PM emissions from brake pads. Tests conducted on asbestos-based brake pads have shown that $32 \%$ of all the particles are airborne [27]. The GM group tested non-asbestos brake pads and found that an average of $35 \%$ of brake pad mass was lost as airborne PM [28], in agreement with the formerly cited study. On the other hand, tests conducted by the Ford group demonstrated that $50 \%$ of the brake wear was emitted as airborne PM, irrespective of the brake materials tested [24]. In a study on three non-steel brake pad linings, an estimated $74-92 \%$ of the total number of brake wear particles turned out to be emitted as $\mathrm{PM}_{2.5}$, corresponding to $12-36 \%$ of the whole particle mass [29]. Of course, the testing and sampling techniques applied during these studies were different. Thus, adequate knowledge of the sampling procedure and different experimental approaches are essential. In air quality studies, a standard term, i.e., emission factor (EF), is used to correlate the amount of aerosol released in the environment to the source causing it [15]. In order to calculate the brake emission factors (BEFs), two main methodologies have been reported in the literature: laboratory test BEFs calculated by direct measurements [24,28-30]; receptor modelling studies in the case of roadside investigations $[11,14,31]$.

Toxicological studies have shown that particle size decides how deep particles can penetrate in the respiratory tract, into the lung tissues, and, thereby, affect the health [32,33], for which composition is important too [34,35]. Though the constituents of brake material differ depending on the manufacturers, there are some metals that can be used to identify the PM contribution coming from brake wear, like iron, copper, antimony, and barium [3]. The materials characterization techniques used to investigate the surfaces of the pad and counterface rotor, as well as on the wear debris, have proved to be paramount to obtain data useful to fully understand the wear process and safeguarding against the harmful emissions. Moreover, through the characterization of the wear products from present brake systems, we could pave a path for the development of new eco-friendly materials, which is definitely a need of the hour. These novel materials should still feature excellent tribological properties, along with lower emission of airborne PM, with particular emphasis on ultra-fine fraction [36].

Many review papers have diligently summarized and updated the state and knowledge of automotive brake materials, sampling techniques, and emissions [3,6,12,21,37-39]. However, looking at the situation from the lens of materials characterization, the subject has not been reviewed substantially, so far. Thus, in this current review, we majorly focused on the main characterization techniques that have been utilized by researchers to explore the brake wear products, as concerns their morphological, compositional, and microstructural aspects. It will be demonstrated that a robust investigation 
of the intricacies of brake wear is possible only by combining different characterization tools. Indeed, multi-analytical protocols are a point of interest in this work.

\section{Brake Pad and Disc Materials}

\subsection{Brake Pads}

Brake pad materials are extremely heterogeneous owing to the presence of multiple macroscopic and microscopic components, bound together by an adhesive. Their formulation is so complex that for manufacturers it is a guarded technology, and some researchers have termed it a form of art [40-44]. Brake pads have been conventionally classified into three main categories: Non-asbestos organic (NAO), low metallic (LM), and semi-metallic (SM) $[3,13]$. They are all regarded as organic friction materials since the matrix of these composites consists of one or more polymeric resin, mostly phenolic [37]. Regardless of the type, they are expected to have a stable coefficient of friction, robust mechanical and thermal characteristics, good compatibility with the counterpart, high wear resistance, low cost, reduced brake noise, and emission rate of PM. These properties are challenging to achieve under different varying parameters, such as temperature, contact pressure, braking power, relative velocity, road, and weather conditions [13,36,45-47]. Table 1 shows the typical components of brake pads. Their relative amounts, depending on the type of the pad that may be suitable for a particular application, influence also the composition (see Section 4.1, Table 6) and microstructural features of the PM produced by the relevant wear mechanisms. Table 2 shows the role and examples of different ingredients: reinforcements, binders, fillers, and friction modifiers, whose relative percentages vary for different types, manufacturers, and regions of the world.

A relatively low friction coefficient has been reported in the literature for NAO-type brake pads. Higher values of friction coefficient are associated with the higher content metallic fibers present in LM. The NAO-type brake pads exhibit relatively low brake noise and low wear rates, but milder braking capacity, particularly at high temperature. Semi-metallic brake pads have a high steel fiber and iron powder content, and low wear rate, but are on average noisier than the other types [24]. The presence of a large number of abrasives in LM pads, results in good braking capacity, even at high temperatures. Most SM formulations contain large quantities of steel wool as reinforcing fiber, providing them better high-temperature braking performance as compared to NAO types.

Wear mechanisms differ for different types of brake pad formulations, with NAO types showing lower PM emissions than LM types: 3-4 times (both particle mass and number) [24]; 45-48\% lesser mass emission than [48]. On the other hand, though SM pads wear less as compared to the NAO types, the released PM is on average smaller in size [49]. Some researchers have proposed that LM-type has high abrasive interaction with the disc, which causes initial tribo-oxidative wear, leading to the formation of contact plateaus (discussed in Section 4.2), featuring high content of iron oxides, mostly coming from the cast-iron disc wear, inducing an increase in "work of adhesion" [50-53]. Neis et al. [54] found that contact plateaus in the case of NAO-type are wider, leading to better local temperature management with a consequently lower number of emitted particles. However, in some cases the costs of NAO- type brake pads can be a limiting factor to their usage. Wahlström et al. [55] tested NAO and LM brake pads against the same rotors and found that LM pads had a higher friction coefficient. This caused more pronounced wear of the rotors, which led to a higher concentration of the airborne emitted PM. This is the reason why NAO pads (more common in the US and Japan) are expected to gain prominence also in Europe, where LM pads are commonly used at the present time.

Figure 1 shows the evolution of brake pads in the US market, where Cu-free pads are rapidly gaining preference, primarily due to the restrictions by the Environmental Protection Agency (EPA). Elimination of copper in NAO pad formulations is ongoing research, and studies by Menapace et al. [36,56] and Aranganathan and Bijwe [57] are providing interesting insights in this regard. 


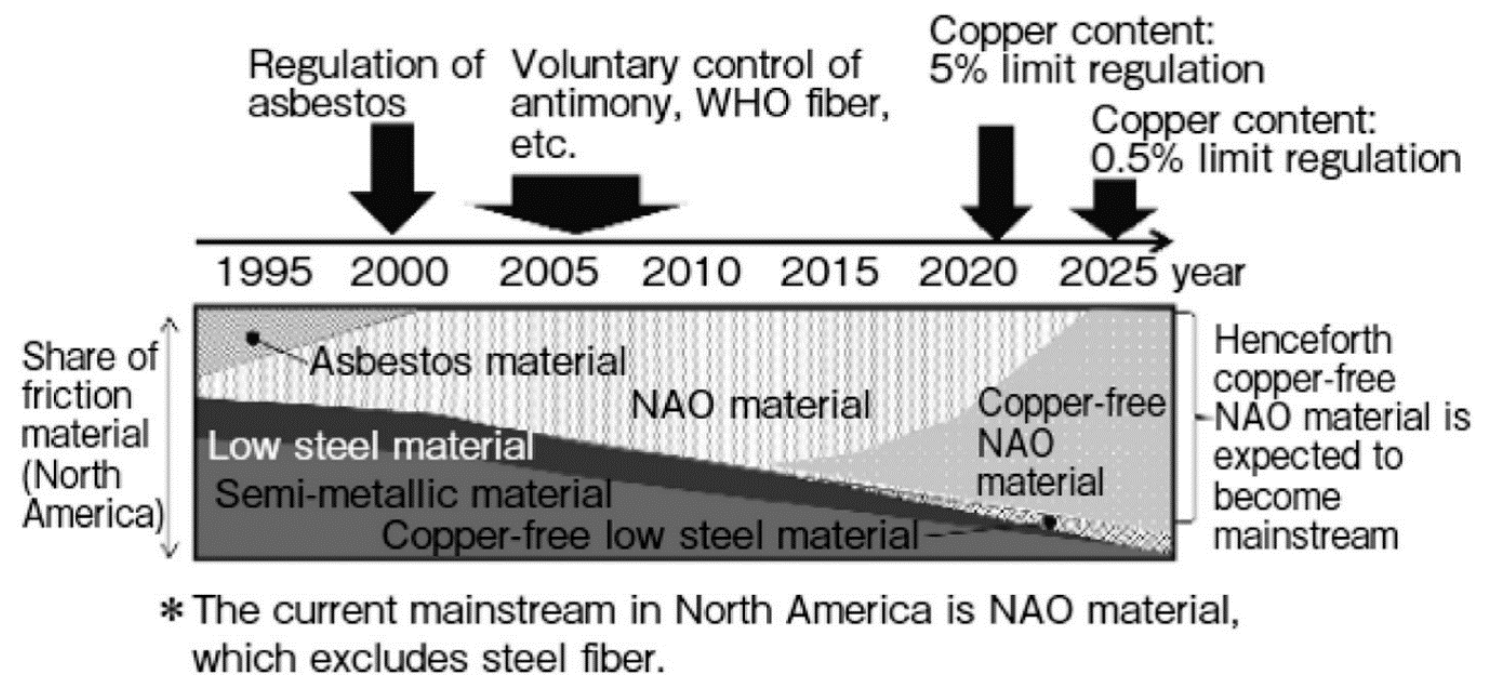

Figure 1. History of changing regulations of the compounds used in North America [21].

\subsection{Cast Iron Discs}

The optimal working of a disc brake unit is also heavily dependent on the proper matching of the pads with the disc. Disc provides an adequate coefficient of friction during sliding against the pad, and also contributes to the cooling of the system, considering that around $90 \%$ of the heat generated during the braking action goes into the disc $[1,58]$. Discs in automotive brake systems are usually made up of pearlitic grey cast iron. Cast iron discs are cost-effective and possess good machinability, hence suitable from the mass production point of view.

Table 1. Brake pads: Types and general properties $[6,13,24,28,37,45,48,59]$.

\begin{tabular}{|c|c|c|c|c|c|c|}
\hline \multirow{2}{*}{ Type } & \multirow{2}{*}{$\begin{array}{l}\text { Primary } \\
\text { Ingredients }\end{array}$} & \multicolumn{4}{|c|}{ Properties } & \multirow{2}{*}{ Applications } \\
\hline & & $\begin{array}{c}\text { Friction } \\
\text { Coefficient }\end{array}$ & Brake Noise & Wear Rate & Fade & \\
\hline NAO & $\begin{array}{l}\% \mathrm{Fe}+\mathrm{Cu} \text { and } \\
\text { their alloys: } 10 \% \text {; } \\
\text { Combination of } \\
\text { inorganic fibers } \\
\text { (glass, carbon, } \\
\text { rubber, etc.) }\end{array}$ & Low & $\begin{array}{c}\text { Less compared } \\
\text { to the } \\
\text { other types }\end{array}$ & $\begin{array}{l}\text { Low wear rate at } \\
\text { low temperatures; } \\
\text { cause less rotor } \\
\text { wear, but poor } \\
\text { performance under } \\
\text { heavy-duty } \\
\text { conditions. }\end{array}$ & $\begin{array}{l}\text { Poor resistance; } \\
\text { sensitive to high } \\
\text { temperatures }\end{array}$ & $\begin{array}{l}\text { Down-sized/ } \\
\text { Compact cars. } \\
\text { Common in the US } \\
\text { and Japan }\end{array}$ \\
\hline LM & $\begin{array}{l}\% \mathrm{Fe}+\mathrm{Cu} \text { and } \\
\text { their alloys: } \\
10-50 \% ; \\
\text { relatively more } \\
\text { abrasive content }\end{array}$ & Medium to high & $\begin{array}{l}\text { More than } \\
\text { NAO types }\end{array}$ & $\begin{array}{l}\text { High wear rate, } \\
\text { with high iron } \\
\text { content in wear } \\
\text { debris. Additionally, } \\
\text { cause more } \\
\text { wear of rotor. }\end{array}$ & High resistance & $\begin{array}{l}\text { Medium-sized cars. } \\
\text { Common in the } \\
\text { European market }\end{array}$ \\
\hline SM & $\begin{array}{l}\% \mathrm{Fe}+\mathrm{Cu} \text { and } \\
\text { their alloys: } \\
50-65 \% ; \\
\text { steel wool fiber } \\
\text { with iron } \\
\text { powder }\end{array}$ & Low to Medium & $\begin{array}{l}\text { High, especially } \\
\text { in humid } \\
\text { conditions due } \\
\text { to corrosion }\end{array}$ & $\begin{array}{l}\text { Low wear rate at } \\
\text { high temperatures } \\
\text { and highest } \\
\text { durability. } \\
\text { Less effective in } \\
\text { extremely cold } \\
\text { weather and also } \\
\text { cause more rotor } \\
\text { wear than } \\
\text { NAO types }\end{array}$ & $\begin{array}{l}\text { Average } \\
\text { resistance }\end{array}$ & $\begin{array}{c}\text { Heavy duty: } \\
\text { commercial buses } \\
\text { and trucks. } \\
\text { Metallic linings } \\
\text { suitable for extreme } \\
\text { braking conditions } \\
\text { (police, sports cars) }\end{array}$ \\
\hline
\end{tabular}

In view of their usage in brake components, they have relatively high hardness, good dry sliding behavior, and damping characteristics. The presence of lamellar graphite, protruding from the surface of the disc during sliding, gives a self-lubricating effect, improves thermal conductivity, thereby providing resistance to the stresses generated during braking $[58,60]$. A drawback of using 
cast iron disc is in its weight, having an impact on the vehicle fuel consumption, and hence emissions. Additionally, it has less corrosion resistance, which can reduce the service life and braking performance in the presence of humidity, road salt, and complex wear mechanisms [61-63].

Table 2. Brake Pads: main ingredients $[3,6,37]$.

\begin{tabular}{|c|c|c|c|}
\hline Component & Range (by Mass) & Functions & Examples \\
\hline Reinforcements & $6-35 \%$ & $\begin{array}{l}\text { Withstanding high frictional } \\
\text { and thermal stresses }\end{array}$ & $\begin{array}{l}\text { Glass fiber, metallic fibers and } \\
\text { particulates (e.g., steel, copper, } \\
\text { brass), ceramics and mineral fibers } \\
\text { (e.g., alumina, silicon carbide, } \\
\text { wollastonite) and organic fibers } \\
\text { (e.g., Kevlar, acrylic) }\end{array}$ \\
\hline Binders & $20-40 \%$ & $\begin{array}{l}\text { Maintaining the structural } \\
\text { integrity of the pads under the } \\
\text { action of high thermal and } \\
\text { mechanical loads }\end{array}$ & $\begin{array}{l}\text { Phenolic resin- also used in a } \\
\text { modified form with toughners, } \\
\text { such as silicone and epoxy. } \\
\text { Other less commonly used resins } \\
\text { are cyanate ester, } \\
\text { thermoplastic polyamide }\end{array}$ \\
\hline Fillers & $15-70 \%$ & $\begin{array}{l}\text { Favoring reduction in cost and } \\
\text { ease of manufacturing. } \\
\text { Additionally, improve the } \\
\text { thermal properties of the pad, } \\
\text { with reduction in noise. }\end{array}$ & $\begin{array}{l}\text { Inorganic, e.g., barium and } \\
\text { antimony sulphate, } \\
\text { calcium carbonate, silicates, } \\
\text { magnesium and chromium oxides, } \\
\text { metal powders; Organic, } \\
\text { e.g., cashew dust, rubber particles }\end{array}$ \\
\hline $\begin{array}{l}\text { Friction Modifiers: } \\
\text { Abrasives and } \\
\text { lubricants }\end{array}$ & $\begin{array}{l}\text { Abrasives: up to } 10 \% \text {; } \\
\text { Lubricants: } 5-29 \%\end{array}$ & $\begin{array}{l}\text { Maintaining an adequate } \\
\text { coefficient of friction. They } \\
\text { also influence the wear rate of } \\
\text { the disc surface and limit the } \\
\text { size of transfer films. }\end{array}$ & $\begin{array}{l}\text { Aluminium oxide, silicon carbide, } \\
\text { quartz, and zirconium oxide and } \\
\text { chromium oxide; } \\
\text { Graphite, carbon black, zinc oxide, } \\
\text { metal sulphides: e.g., antimony } \\
\text { trisulphide, tin sulphide }\end{array}$ \\
\hline
\end{tabular}

Aluminium alloys with surface treatments (spraying, anodizing, plasma electrolytic oxidation) and aluminium-based metal matrix composites have been suggested as possible alternatives to cast iron. Their favorable properties are lower density, good strength, wear, and corrosion resistance [64-68]. However, their maximum resistance to elevated temperatures lies in the range $400-500{ }^{\circ} \mathrm{C}$, and they also have a higher coefficient of thermal expansion than cast iron. Moreover, their high inherent cost is definitely an important limiting factor in their usage.

For improving the tribological properties of cast-iron discs, some researchers have proposed cryogenic treatments $[69,70]$, conventional heat treatment processes, viz. quenching, tempering, and austempering $[48,58,71]$, and coatings $[18,72]$. The cryogenic treatment, involving liquid nitrogen, affects not just the surface but the entire cross-section of the disc and improves its wear resistance. Using conventional heat treatment processes, Straffelini et al. [58] showed that the wear rates of both cast-iron disc and LM friction material could be reduced by one order of magnitude using heat-treated cast-iron discs. High-velocity oxygen-fuel (HVOF)-coated cast-iron discs have superior properties, owing to the fine microstructure of the coating, coupled to high density and hardness. Moreover, the coated discs perform better than uncoated ones in terms of particle emissions, as demonstrated in a study, using pin-on-disc (PoD, see Section 3.1.2) testing [72]. Menapace et al. [18] conducted a comparative investigation on the emissions from uncoated and WC-CoCr-coated cast iron discs against the same LM pads, using a dyno-bench test rig. From the characterization of the collected particles, in the $2.5 \mu \mathrm{m}$ to $30 \mathrm{~nm}$ range, a consistent reduction in the emission, along with the concentration of iron oxide, was evidenced. On the basis of a similar investigation and experimental study, the design of a disc brake system for a European pad and heat-treated rotor was analyzed under the EU funded REBRAKE project, which could provide a $32 \%$ reduction in $\mathrm{PM}_{10}$ emission [48]. At the same time, a $65 \%$ reduction in $\mathrm{PM}_{10}$ was possible using a NAO pad and the same heat-treated rotor. 


\section{Brake Wear Products: Sampling Techniques}

Different methods have been reported in the literature for estimating the magnitude and effects of non-exhaust emissions. These can be classified as studies based on emission estimates and include simulator studies, inverse modelling, and emission inventories. They provide useful indications for source apportionment, based on dispersion and receptor models. Although the different methodologies should provide coherent results, a substantial difference exists, as concerns the sampling approaches. In this respect, indoor lab and bench tests may benefit from more controlled experimental conditions, compared to the outdoor environmental PM sampling. These aspects are reviewed in this section, with reference to simulator (pin-on-disc and dynamometer) and source apportionment studies, in both cases with respect to brake wear products.

\subsection{Simulator Studies}

Several experimental setups have been proposed for simulating real disc brakes, such as the friction assessment screening test (FAST) [73], the reduced-scale dynamometers [74,75], the chase machine [76], the mentioned pin-on-disc, and full-size dynamometer tests. This latter can reproduce real braking conditions, as they are carried out on real components according to specific driving cycles $[30,50,77]$. In the laboratory, we can run a test under controlled air cleanliness, thus eliminating the problem associated with the field tests, where it can be difficult to distinguish the brake wear from other traffic generated aerosols [78]. A precise contact between pad and disc can be maintained using calliper supports during tests on a dynamometer. Dynamometer tests may be designed for aggressive testing, as in real-life driving conditions when intense pressure and decelerations may be encountered. Still, factors such as real variable speed and weather conditions cannot be incorporated [39]. Pin-on-disc tests, on the other hand, are relatively simplified ones, as they are usually carried out under constant contact pressure and sliding velocity. In general, they are beneficial in the early development phases of new friction materials, and can be carried out at relatively lower costs, shorter time span, and are particularly effective in correlating wear mechanisms with the relevant test parameters $[50,51,55]$.

A critical comparison between PoD and brake dynamometers for their relevance to brake emission studies, from the same set of tribological pairs, i.e., discs and friction materials/pads, has been proposed by Federici et al. [50], even in view of a reliable and effective transfer of knowledge. It turned out that, although the wear mechanisms observed in the two setups were similar, the wear coefficient for dynamometer tests were one order of magnitude lower, with unavoidable consequences on the emission rate. Similarly, Nosko and Olofsson [79] and Alemani et al. [17] conducted tests on PoD, and observed that the maximum amount of wear particles was emitted below $200{ }^{\circ} \mathrm{C}$, while on a dynamometer test, Garg et al. [28] noted highest mass wear at $400{ }^{\circ} \mathrm{C}$ and lower wear rate below $300{ }^{\circ} \mathrm{C}$. Such variations in results are bound to happen because of the intrinsic differences in wear mechanisms, influencing the particle formation at different temperatures, through the formation and disruption of contact plateaus (rapid in case of PoD because of limited contact area) with different properties.

\subsubsection{Dynamometer}

Measurement of brake particles on dynamometers is considered as the most effective and reliable approach. Two innovative techniques for controlled PM measurement were developed by Garg et al. [28] and Sanders et al. [80], with the former group using a closed disc and the latter group using open disc brake dynamometers. Table 3 highlights the important relevant techniques and parameters of the tests conducted by different research groups, along with the emission factors obtained. 
Table 3. Overview of selected dynamometer studies $[15,30,45]$.

\begin{tabular}{|c|c|c|c|c|}
\hline References & $\begin{array}{l}\text { Brake Pads and } \\
\text { Test Stands }\end{array}$ & Test Conditions & $\begin{array}{l}\text { Particle Quantification; } \\
\text { Sampling Efficiency }\end{array}$ & Emission Factors \\
\hline Garg et al. [28] & $\begin{array}{l}\text { SM and NAO; } \\
\text { Closed disc brake } \\
\text { dynamometer }\end{array}$ & $\begin{array}{c}\text { General Motors } \\
\text { BSL-035 driving } \\
\text { Cycle. } \\
\text { Clean air supply and } \\
\text { without isokinetic } \\
\text { sampling. } 50 \text { to } 0 \mathrm{~km} / \mathrm{h} @ \\
\text { deceleration of } 2.94 \mathrm{~m} / \mathrm{s}^{2} \text {. }\end{array}$ & $\begin{array}{l}\text { TSP sampling, } \\
\text { size-resolved by MOUDI; } \\
\sim 55 \% \text { for } 5 \mathrm{~mm} \\
\text { particle diameter }\end{array}$ & $\begin{array}{c}\mathrm{PM}_{10}, \mathrm{PM}_{2.5} \text { and } \mathrm{PM}_{0.1} \\
\mathrm{BEFs} \text { of } 2.9-7.5,2.1-5.5 \\
\text { and } 1.2-3.1 \\
\mathrm{mg} / \mathrm{km} / \text { vehicle } \\
\text { respectively }\end{array}$ \\
\hline Sanders et al. [24] & $\begin{array}{l}\text { LM, SM, and NAO; } \\
\text { Open disc brake } \\
\text { dynamometer }\end{array}$ & $\begin{array}{c}\text { General Motors } \\
\text { UDP driving cycle } \\
\text { AMS driving cycle. } \\
\text { Isokinetic sampling and } \\
\text { without clean air supply. } \\
\quad 90 \text { to } 0 \mathrm{~km} / \mathrm{h} @ \\
\text { deceleration of } 1.6 \mathrm{~m} / \mathrm{s}^{2} \text {. }\end{array}$ & $\begin{array}{c}\text { TSP sampling, } \\
\text { size-resolved by MOUDI } \\
\text { and ELPI; } 99-97 \% \text { for } 2 \mathrm{~mm} \\
\text { particle diameter } \\
86-67 \% \text { for } \\
10 \mathrm{~mm} \text { particle diameter }\end{array}$ & $\begin{array}{l}\text { Average } \mathrm{PM}_{10} \mathrm{BEF} \text { of } \\
8.1 \mathrm{mg} / \mathrm{km} / \text { vehicle for } \\
\text { low-metallic, } \\
\text { semi-metallic, } \\
\text { and NAO }\end{array}$ \\
\hline Iijima et al. [29] & $\begin{array}{l}\text { NAO; Open } \\
\text { disc brake } \\
\text { dynamometer }\end{array}$ & $\begin{array}{c}\text { JASO C427-88 } \\
\text { driving cycle. Without } \\
\text { isokinetic sampling and } \\
\text { supply of clean air. } \\
50-80 \text { to } 0 \mathrm{~km} / \mathrm{h} \\
\text { @ deceleration of } 3 \mathrm{~m} / \mathrm{s}^{2} \text {. }\end{array}$ & $\begin{array}{l}\text { Aerodynamic particle } \\
\text { sizer (APS,) } \\
\text { Tokyo Dylec Co., Japan }\end{array}$ & $\begin{array}{c}\mathrm{PM}_{10} \text { value of } \\
5.8 \mathrm{mg} / \mathrm{km} / \text { vehicle and } \\
\mathrm{PM}_{2.5} \text { value of } \\
3.9 \mathrm{mg} / \mathrm{km} / \text { vehicle }\end{array}$ \\
\hline Hagino et al. [81] & $\begin{array}{l}\text { NAO; Closed } \\
\text { disc brake } \\
\text { dynamometer }\end{array}$ & $\begin{array}{c}\text { Own urban driving } \\
\text { program (deceleration }< \\
3.0 \mathrm{~m} / \mathrm{s}^{2} \text {, max. speed } 60 \\
\mathrm{~km} / \mathrm{h} \text { ). With clean air } \\
\text { supply and without } \\
\text { isokinetic sampling. }\end{array}$ & DustTrak + Impactor & $\begin{array}{c}0.006-0.016 \mathrm{mg} \text { of } \\
\mathrm{PM}_{10} / \text { braking/ } \\
\text { wheel }\end{array}$ \\
\hline Hagino et al. [77] & $\begin{array}{c}\text { NAO; Closed disc } \\
\text { brake } \\
\text { dynamometer }\end{array}$ & $\begin{array}{l}\text { Wear test-JASO C427 } \\
\text { (deceleration } 2.94 \mathrm{~m} / \mathrm{s}^{2}, \\
\text { max. speed } 50 \mathrm{~km} / \mathrm{h}) ; \\
\text { Japanese exhaust emission } \\
\text { tests }(\mathrm{JC} 08 / \mathrm{JE} 05)(\text { max. } \\
\text { speed } 90 \mathrm{~km} / \mathrm{h} \text { ). With clean } \\
\text { air supply and without } \\
\text { isokinetic sampling. }\end{array}$ & DustTrak + Impactor & $\begin{array}{c}0.04-1.4 \mathrm{mg} \text { of } \\
\mathrm{PM}_{10} / \mathrm{km} / \text { vehicle } \\
0.04-1.2 \mathrm{mg} \text { of } \\
\mathrm{PM}_{2.5} / \mathrm{km} / \text { vehicle }\end{array}$ \\
\hline Perricone et al. [30] & $\begin{array}{l}\text { NAO, LM; Closed } \\
\text { disk brake } \\
\text { dynamometer }\end{array}$ & $\begin{array}{l}\text { Modified SAE J } 2707 \text { (max. } \\
\text { deceleration } 3.92 \mathrm{~m} / \mathrm{s}^{2} \text {, } \\
\text { max. speed } 100 \mathrm{~km} / \mathrm{h} \text { ). } \\
\text { With clean air supply and } \\
\text { isokinetic sampling. }\end{array}$ & $\begin{array}{c}\text { Mass of filters, } \\
\text { Number concentration } \\
\text { (ELPI + cascade impactor); } \\
\text { 100-99.8\% for } 1 \mu \mathrm{m} \text { particle } \\
\text { diameter, } 94.5-88.2 \% \text { for } \\
10 \mu \mathrm{m} \text { particle diameter. }\end{array}$ & $\begin{array}{l}\text { BEFs of } 8.5-46.4 \\
\mathrm{mg} / \mathrm{stop} / \mathrm{brake} \\
\text { and a number } \\
\text { emission factor of } \\
8-153 \mathrm{~N} \times 10^{10} / \\
\text { stop/brake }\end{array}$ \\
\hline
\end{tabular}

Emission factors (EFs) are very important tools used by environmental protection agencies to correlate the quantity of PMs emitted in the atmosphere with its source. Since brake wear contributes a significant amount of PM to the transport sector, it is essential to estimate brake emission factors (BEFs). In direct tests, BEFs can be determined in controlled conditions, although the effects of additional parameters, such as brake, rim, and wheel geometry; the passage of air through them; vehicle weight, maintenance, servicing, and driving style, cannot be fully accounted for $[3,15,24,30]$.

Available studies have incorporated decelerations ranging from 0.1 to $7.9 \mathrm{~m} / \mathrm{s}^{2}$ and initial speeds from 7 to $100 \mathrm{~km} / \mathrm{h}$ [82]. These variations, coupled with the differences in intensity and frequency of the braking events, significantly influence the wear mechanisms and inherent properties of the emitted particles. As a direct consequence, deviations in emission factors, and composition of particles are reported. For instance, Chasapidis et al. [82] noted that braking to a full stop from $50 \mathrm{~km} / \mathrm{h}$ instead of $30 \mathrm{~km} / \mathrm{h}$ could cause the emission of more than $40-100 \%$ particles. Lower deceleration rate further enhanced particle emission because of longer contact between the pads and the disc. Even during non-braking events, i.e., when the brakes have been fully released and while accelerating, brake wear particles can still be generated. This has been attributed either to resuspension of the wear particles from the surface of pad and disc, or an alternative mechanism, the brake drag (uncontrolled contact between pad and disc even when brakes are not pressed) has been observed by Zum Hagen et al. [83,84] 
and by Hagino et al. [77]. Additionally, if we look at closed disc dynamometer, only a few studies have considered isokinetic sampling $[24,30,80,85]$ and clean air supply $[28,30,77,81,85]$. These are essential requirements for high sampling efficiency, and to ensure that all the collected particles are emitted from the brake materials in an unbiased manner, thus eliminating the chances of either overestimation or underestimation of particle concentration $[83,85]$. Thus, a valid question always remains, concerning how the laboratory results can be transferred to real-world driving conditions.

\subsubsection{Pin-on-Disc}

The logic behind using a PoD setup in the study of brake materials is mainly related to the possibility of exploring fundamental tribological aspects. Indeed, even though the drag and constant velocity conditions, and the part size too, are rather different from real brake conditions, still the flat-on-flat contact geometry of the $\mathrm{PoD}$ tests is interesting to control and assess specific wear mechanisms. In this context, the relatively simple geometry of the PoD test rig turns out to be an economical and efficient method of collecting the wear debris, by varying velocity, pressure as well as the contact temperature between the pin and the disc. It has been reported that the product of pressure and velocity in real brake systems varies between 0.3 and $20 \mathrm{MPa}-\mathrm{m} / \mathrm{s}$ [86,87]. An adequate value, usually below $10 \mathrm{MPa}-\mathrm{m} / \mathrm{s}$, is found to be suitable on the PoD setup for collecting performance data of the materials under study. The atmosphere around the setup can be controlled, and most of the debris, both airborne and deposited, can be collected. Table 4 shows the findings of selected PoD studies.

The increasing importance of studying the emission from wear tests has led to the development of a novel tribometer setup equipped with on-line instruments that can measure particle mass, size, and concentration [88]. The noteworthy aspect which can be inferred from these tests is that they have yielded unimodal, bimodal as well as multimodal size distribution peaks (see Table 4). For instance, unimodal peak with size distribution at $0.4 \mu \mathrm{m}$ [26], bimodal peaks at $0.35 \mu \mathrm{m}$ and $0.55 \mu \mathrm{m}$ [89], and multimodal peaks at 0.1, 0.28, 0.35, and $0.55 \mu \mathrm{m}$ [55]. Verma et al. [90] conducted tests on LM pads and collected the airborne wear particles in the $0.006 \mu \mathrm{m}$ to $10 \mu \mathrm{m}$ size range, with the mass distribution peak at around $5 \mu \mathrm{m}$. At the same time, the number distribution of nanosized particles $(0.1 \mu \mathrm{m})$ outnumbered the micron-sized particles by more than three orders of magnitude. As concerns the contact temperature, Alemani et al. [17] observed that at a critical value in between $165^{\circ} \mathrm{C}$ and $190{ }^{\circ} \mathrm{C}$, ultrafine particle emissions rose $4-6$ orders of magnitude (almost $100 \%$ of the total particle number). However, below $165^{\circ} \mathrm{C}$, fine particles still outnumbered coarse and ultrafine particles, and coarse particles formed the bulk of the PM mass. This again highlights the fact that brake wear particles release particles in a broad size range and that the ultrafine component, being by far the most important under several operating conditions, would deserve particular attention.

Table 4. Overview of selected pin-on-disc (PoD) studies.

\begin{tabular}{|c|c|c|c|c|c|}
\hline \multirow{2}{*}{ References } & \multirow{2}{*}{ Brake Pad } & \multirow{2}{*}{$\begin{array}{c}\text { Particle } \\
\text { Monitoring/Counting } \\
\text { Instruments }\end{array}$} & \multirow{2}{*}{$\begin{array}{l}\text { Particle Size } \\
\text { Range ( } \mu \mathrm{m})\end{array}$} & \multicolumn{2}{|c|}{ Particle Size Distributions $(\mu \mathrm{m})$} \\
\hline & & & & Major & Minor \\
\hline Mosleh et al. [91] & SM & Laser scattering analyzer & $0.04-262$ & 0.35 & $2-15$ \\
\hline Wahlström et al. [55,89]; & LM, NAO & $\begin{array}{c}\text { GRIMM Aerosol } \\
\text { Spectrometer, TSI DustTrak }\end{array}$ & $0.25-32$ & $0.35[55,89]$ & $\begin{array}{c}0.28,0.55[55] \\
0.550[89]\end{array}$ \\
\hline $\begin{array}{l}\text { Verma et al., [90]; } \\
\text { Lyu et al. [92] }\end{array}$ & LM & $\begin{array}{l}\text { Dekati electrical } \\
\text { low-pressure } \\
\text { impactor (ELPI+) }\end{array}$ & $0.006-10$ & $\begin{array}{c}0.017[90] ; \\
0.016,0.03, \\
0.054[92]\end{array}$ & 0.03, $0.06[90]$ \\
\hline Alemani et al. [17] & LM, NAO & $\begin{array}{l}\text { Optical particle } \\
\text { sizer (OPS), ELPI+ }\end{array}$ & $0.0056-10$ & $\begin{array}{c}0.19-0.29 \\
0.011-0.034\end{array}$ & $0.9,1.7$ \\
\hline
\end{tabular}

\subsection{Source Apportionment: Trace Elements for Brake Wear}

Outdoor environmental monitoring studies, focused on PM emission, would feature as an important methodological step in the identification and source apportionment of the pollutants. The aim of the source apportionment (SA) models is to re-construct the emission impacts from different 
sources of atmospheric pollutants [93,94]. A fundamental prerequisite in this sort of studies is effective sampling instrumentations and protocols, which are capable to collect PM specimen representative of the actual environmental conditions. The instruments used in the field, although featuring some analogy to the lab equipment, exhibit peculiar aspects, to provide reproducible and comparable results, and to comply with legislation and standards $[2,95,96]$.

Receptor modelling (RM) is one of the most commonly used techniques to implement SA at the regional level, especially for sources of airborne PM. It involves solving a mass balance equation using multivariate analysis, to account for all the chemical species in the samples of atmospheric pollutants collected from a site (receptor), as contributions from different independent sources [97,98]. RM is broadly categorized into two types: microscopy models and chemical models. In certain cases, identification of the chemical composition of the pollutants obtained from the receptor is the viable option, as obtaining the local source profile can be difficult [99]. Road dust is an accumulation of different organic and inorganic pollutants, and at the same time, it becomes an overall new source of pollution in the form of resuspension. While apportioning pollutants to the brake system, researchers have to differentiate between particle emissions from brake abrasion and resuspension. Thus, unique tracers for brake emissions are required to separate them from other sources.

Brake pads may contain $\mathrm{Sb}$, in the form of antimony oxide $\left(\mathrm{Sb}_{2} \mathrm{O}_{3}\right)$ and stibnite $\left(\mathrm{Sb}_{2} \mathrm{~S}_{3}\right)$, of which the latter can be easily decomposed to stable oxide forms during brake abrasion. $\mathrm{Sb}_{2} \mathrm{~S}_{3}$ improves fade and wear resistance $[100,101]$, and also serves to reduce low-frequency brake noise and vibrations [102]. Antimony in the form $\mathrm{Sb}(\mathrm{III})$ and $\mathrm{Sb}(\mathrm{V})$ has been reported in atmospheric PM [103], and road dust [104]. Industrial activities have little impact on the Sb concentration, making it a potential candidate to be used as a tracer element. Budai and Clement [105] estimated that approximately $70 \%$ of the brake wear produced metals $(\mathrm{Cu}, \mathrm{Sb})$, which are left behind the curb in case of precipitation, possibly returning to the atmosphere as resuspended particles, as the wet dust dries. This was supported by the laboratory studies [24,106], which estimated that $30-50 \%$ of the brake wear products (depending on the friction lining composition and braking conditions) belong to the fraction which is deposited easily, and the rest becomes airborne. Many researchers have suggested the use of characteristic $\mathrm{Cu} / \mathrm{Sb}$ ratios for distinguishing brake pad emissions from other sources. However, it is to be noted that these ratios can differ depending on the brake pad types [24], and geographical location [49]. Similarly, Pant et al. [107] reported that the bulk brake dust from the selected brake pads in an Asian country was found to be richer in $\mathrm{Ti}(0.12 \%), \mathrm{Sb}(1.12 \%)$, and $\mathrm{Cu}(0.49 \%)$, while in a European country to be abundant in $\mathrm{Ba}$ $(0.12 \%)$, and $\mathrm{Sb}(0.16 \%)$. These lead to different $\mathrm{Cu} / \mathrm{Sb}$ ratios report, for instance, of 11.5 for NAO brake lining [29], and 1.33 for SM [108]. Hulskotte et al. [109] found an average value of 4.6 for used brake pads in the Netherlands, while in their field study, Pant et al. [107] found the values as $4.95 \pm 0.50$, $7.50 \pm 0.79$, and $11.5 \pm 0.82$ at different sites. In certain cases, manufacturers may substitute antimony sulphides with tin sulphides $\left(\mathrm{SnS} / \mathrm{SnS}_{2}\right)$, as these can fulfil the role of friction stabilizer, along with providing a reduction in wear of pad and disc $[77,110]$. Additionally, under the $\mathrm{Cu}$-free brake initiative by the US EPA [111], it has been proposed to reduce $\mathrm{Cu}$ content in pads to 0.5 percent by the year 2025, and similar approaches are expected to be followed in other regions of the world. This will definitely have an impact on $\mathrm{Cu} / \mathrm{Sb}$ ratio and thus, attention is required in this regard for it to be used in apportionment studies.

Other commonly used trace elements are, in addition to the already mentioned: Ba, even Fe and $\mathrm{Zn}$. However, zinc is primarily used to characterize tire wear, since used to coat the reinforcing steel wires $[21,32,112]$. Iron is a dominant heavy metal in road dust samples; this is consistent with the laboratory studies conducted on brake pads, involving either the chemistry of the friction layer [113], or real-time monitoring of emitted airborne particles [90]. The outcome is in both cases that the majority of iron, and relevant oxides, come from the cast-iron brake discs. For the sake of completeness, it is important to mention, as concerns the contributions to iron in environmental PM, also those coming from tire wear and resuspension [114]. Still, regarding barium, this is another marker element for brake dust particles, considering that it is often used as a filler material for brake pads, in the form of 
barite $\left(\mathrm{BaSO}_{4}\right)$. Other sources of environmental barium are quite a few, and this renders this element an effective tracer of PM emitted from brake systems. Indeed, Gietl et al. [114] found that on average Ba comprises $1.1 \%$ of the brake wear emissions ( $\mathrm{PM}_{10}$ particles), better if in association with copper, for a more reliable PM source assessment $[115,116]$. High regression coefficients have been obtained between $\mathrm{Fe}$ and $\mathrm{Cu}, \mathrm{Sb}$, and Ba in brake wear particles [114,117,118], indicating that they are primarily produced by brake wear. Some other elements have also been proposed for the identification of PM emitted from brake systems (see Table 5). Valotto et al. [119] studied the road dust collected in Venice mainland, Italy, and identified brake wear as a significant pollutant source in the monitored area, based on the higher concentrations of $\mathrm{Cr}, \mathrm{Fe}, \mathrm{Mo}, \mathrm{Sb}$ and, to a lesser extent, of $\mathrm{Mg}, \mathrm{Co}, \mathrm{Ni}, \mathrm{Cu}$, $\mathrm{Pb}$. Adamiec et al. [10] noted the presence of $\mathrm{Ti}, \mathrm{Cr}$, and $\mathrm{Cu}$, and recognized them as key tracers of brake wear emissions, in their samples collected from the motorway and urban roads in Poland. Moreover, they noted that since in the city more braking is required and because of low air circulation, higher contamination along with resuspension takes place.

Table 5. Overview of common trace elements for particulate matter (PM) from road vehicle brakes.

\begin{tabular}{ccc}
\hline References & Region of Study & Trace Elements \\
\hline Adamiec et al. [10] & Katowice, Poland & $\mathrm{Ti}, \mathrm{Cr}, \mathrm{Cu}$ \\
Beddows et al. [9] & Birmingham, U.K. & $\mathrm{Ba}, \mathrm{Fe}$ \\
Budai and Clement [105] & Budapest, Hungary & $\mathrm{Cu}, \mathrm{Sb}, \mathrm{Pb}, \mathrm{Zn}$ \\
Valotto et al. [119] & Venice, Italy & $\mathrm{Cr}, \mathrm{Fe}, \mathrm{Mo}, \mathrm{Sb}$ \\
Prakash et al. [120] & Delhi, India & $\mathrm{Fe}$ \\
Jeong et al. [115] & Toronto, Canada & $\mathrm{Cu}, \mathrm{Ba}$ \\
Alves et al. [116] & São Leopoldo and Canoas, Brazil & $\mathrm{Cu}, \mathrm{Ba}$ \\
Yan et al. [104] & Shanghai, China & $\mathrm{Sb}$ \\
Xue et al. [121] & California, US & $\mathrm{Sb}$ \\
\hline
\end{tabular}

To complete the picture of field tests, it is worth mentioning a sort of "enclosure" approach, exploiting a PM sampler attached to the outer side of a real wheel [84]. Similar to what happens in a lab setup, the airflow entering the brake systems carries the wear particles to a suitable counter, providing the relevant real-time emission factors. The investigation is interesting, as it highlights the anomalous behavior observed as a consequence of the overheating inducted into the instrumented wheel by the limited cooling, due to the sampling cover.

\section{Characterization of Brake Wear Products}

Particle size distribution obtained during the sampling of brake wear debris can provide elementary knowledge about particles, but is not sufficient for further analyses and development of the brake materials. The wear mechanisms involved in the braking action, that cause particle emissions in the first place, influence also the chemical composition, shape, dimensions of the particles. A combination of experimental tools is generally needed for a complete characterization of the emitted particles. In the case of the field study, these tools are fundamental for apportioning a pollutant to its source, and also for understanding the transport mechanisms of the pollutants. These outputs, either from laboratory studies or field tests, can lead either to set the upper limit for a particular harmful ingredient (for example, copper and antimony), or altogether eliminate it (for example asbestos), opening the path to the development of clean friction materials. Figure 2 depicts this role of characterization techniques in minimizing the negative health impacts of brake wear debris. 


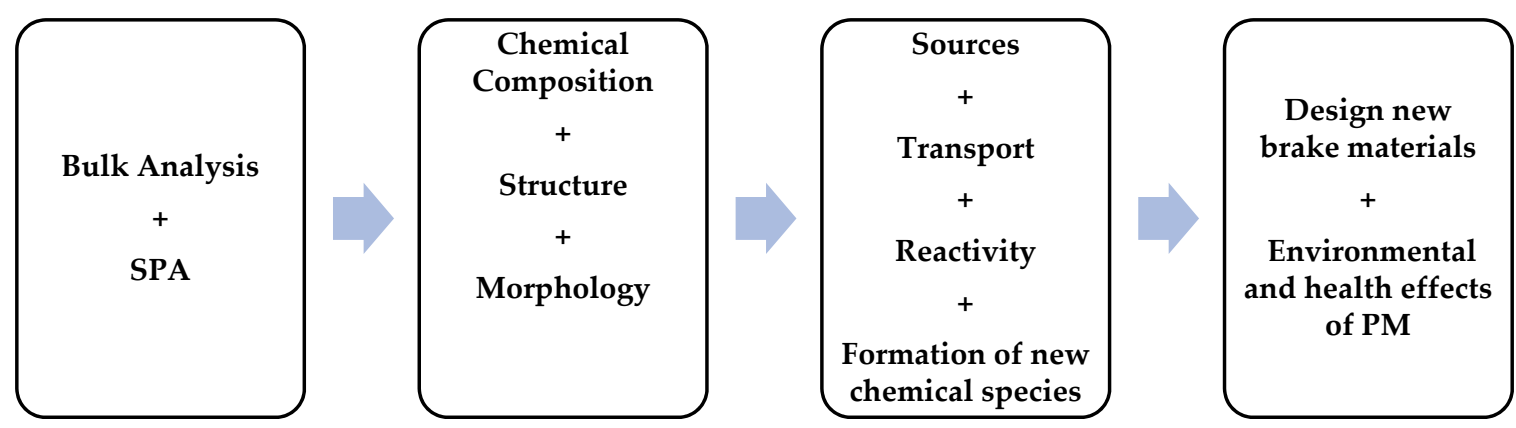

Figure 2. Characterization flow diagram (SPA = single particle analysis).

For a better characterization of the emitted particles the knowledge of the composition of the brake materials, in particular brake pads, is paramount, notwithstanding the obvious changes introduced by the wear mechanisms and the interaction with the outer atmosphere. Moreover, considering that an important fraction of the emitted particles comes from the disruption of the friction layer, its main chemical and crystallographic aspects are interesting in the present context.

\subsection{Characterization of Bulk Brake Materials}

The knowledge of the chemical composition of brake pad formulations is an essential prerequisite for understanding the wear mechanisms and relevant transformations, even as concerns the potential health relevance [109]. A detailed analysis of the bulk sample is critical especially for gauging the potential toxicity of the materials used in the formulation, like copper and antimony. Considering the complexity of the proprietary mixes used for the production of brake pads, involving both organic and inorganic components, it is intrinsically challenging to evaluate the precise composition of the brake pads. Nonetheless, this is not strictly required considering the information that is interesting in this respect. Concerning the discs, being mostly made of cast iron, the key point is the overwhelming presence of iron, also in the emitted particles, usually as oxides, i.e., hematite $\left(\mathrm{Fe}_{2} \mathrm{O}_{3}\right)$ and magnetite $\left(\mathrm{Fe}_{3} \mathrm{O}_{4}\right)$.

$\mathrm{X}$-ray fluorescence (XRF) spectrometry works on the principle of emission of characteristic X-rays induced by an X-ray beam impinging onto the sample surface. Qualitative and quantitative analyses can be carried out by determining the energy/wavelength of the emitted photons $[122,123]$ thanks to suitable detection systems and relevant data analysis methods. Hulskotte et al. [109] studied a set of 65 used brake pads and 15 brake discs using XRF. They noted that though Fe and $\mathrm{Cu}$ were the dominant metals, their ratio varied across the pads tested, and amongst non-metals, $C$ formed the major chunk. However, XRF is not the best technique to detect and, above all, quantify lightweight elements, such as $C$ and $O$ from brake pads $[44,109,124,125]$. Another related technique, widely cited in the literature for determining brake pad compositions, is energy-dispersive X-ray spectroscopy (EDXS), often embedded in scanning and transmission electron microscopes, SEM and TEM, respectively. EDXS too, cannot provide reliable concentrations of light elements [90,125], a limitation that can be overcome with alternative techniques, like the inductively coupled mass spectrometry (ICP-MS) [126]. Accurate information regarding the phase composition of the bulk materials can be obtained through X-ray diffraction (XRD), which becomes particularly valuable when data analysis is based on a full pattern fitting procedure based on the Rietveld method [127,128], as done in $[18,48,129]$. On the basis of phase composition, the bulk materials can be classified into the categories discussed in Section 2, and specific properties, for instance, abrasive character and the effect of present lubricants on it, can be gauged. A higher abrasive content can influence the composition of the friction layer, with high iron oxide content due to the tribo-oxidative wear of the disc. Table 6 highlights the wide range of elemental compositions detected in the brake pads tested in selected studies. 
Table 6. Element weight percentages for brake pads from selected studies: non-asbestos organic (NAO) $[17,44,52,89,130]$, low-metallic (LM) $[17,52,58,89,92,125,130,131]$ and semi-metallic (SM) $[13,130]$.

\begin{tabular}{cccc}
\hline Elements & NAO & LM & SM \\
\hline $\mathrm{Mg}$ & $0.2-13.6$ & $0.8-16.1$ & $0-0.68$ \\
$\mathrm{Al}$ & $0.4-13.8$ & $1.38-17.8$ & $1.1-2.7$ \\
$\mathrm{Si}$ & $0.3-7.4$ & $0.1-6.8$ & $2.89-5.47$ \\
$\mathrm{~S}$ & $1.28-9.3$ & $1.71-7.7$ & $0-4.62$ \\
$\mathrm{~K}$ & $0-6.1$ & $0-7.8$ & $0-0.27$ \\
$\mathrm{Ca}$ & $1-25.57$ & $0-9.34$ & $0-10.08$ \\
$\mathrm{Ti}$ & $0-27.6$ & $0-10.9$ & $0-0.21$ \\
$\mathrm{Fe}$ & $0.7-21.2$ & $4.2-59.8$ & $34.38-71.3$ \\
$\mathrm{Cu}$ & $0-35.6$ & $2.9-16.7$ & $4.09-19.67$ \\
$\mathrm{Zn}$ & $0-14.9$ & $0.6-15.8$ & $0-0.75$ \\
$\mathrm{Zr}$ & $0-30.6$ & $0-24.7$ & $0-0.03$ \\
$\mathrm{Sn}$ & $0-7.5$ & $0-9.4$ & - \\
$\mathrm{Ba}$ & $0-27.7$ & $0-3.9$ & - \\
$\mathrm{Sb}$ & $0-4.01$ & $0-6.94$ & - \\
$\mathrm{Cr}$ & $0-4$ & $0-3.6$ & $0-0.05$ \\
\hline
\end{tabular}

\subsection{Characterization of the Friction Layer}

The amount of wear during braking has a direct impact on the life of the brake components, namely pads and discs. A fundamental factor in this is the formation of a stable friction layer. The ingredients present in friction material, particularly reinforcements (hard and tough metallic/ceramic particles and fibers in the size range 100-1000 $\mu \mathrm{m}$ ), play a fundamental role in the formation of the so-called primary plateaus of the friction layer. Thereafter, growth in the friction layer has been attributed to the accumulation and the compaction of tiny wear fragments, piling up at the primary plateaus. These parts of the friction layer are usually named as secondary plateaus [124,132-134]. During fragmentation of the first body materials, wear particles of different sizes are formed. Particles are either released into the atmosphere and become airborne or, if sufficiently large, fall on the ground. Those fragments which remain trapped in between the mating surfaces, possibly re-fragmented, are compacted and become part of a stable friction layer. The thickness of this layer can be from a few up to several tens of microns $[134,135]$. It is obviously expected that all the phases present in the bulk materials, along with the new phases formed during the involved mechanical phenomena: severe shear deformation, impact $[36,49]$, and tribo-oxidation of the disc $[44,50]$, to be homogeneously mixed at nano-scale in the friction layer [38]. With an emphasis on these nano-structured features of the friction layer, transmission electron microscopy (TEM)-related methods are most appropriate for morphological, structural, and compositional characterization.

Topography information from the optical microscope (OM), although with a lower resolution and depth of field, still provides an interesting insight into the microscopic features of the friction layer surface, as concerns for instance the presence of carbonaceous materials, such as graphite, butadiene rubber, petroleum coke; and inorganic components, such as $\mathrm{Cu}$, Fe and brass chips, iron powder, grains of oxides, metal sulphides $[13,22,23,52,136]$. It has also been used in observing the grooves formed on the disc covered with transferred particles from the friction layer or native oxides [52,58]. This particular issue has received a benefit from the usage of the scanning ion microscopy (SIM) technique. Disc surface grooves show a different contrast, depending on if they are filled or not with wear debris $[137,138]$.

The discontinuous nature of the friction layer, i.e., featuring "uncovered areas" on the pad and disc surface, has been associated with phases having lubricating properties, such as graphite, coke, and vermiculite. The microstructure of these favor an easy slip process for the wear debris, and hence the friction layer adheres most prominently onto the metallic materials like deformed $\mathrm{Cu}$ and Fe [23,139]. Such materials act as the load-carrying agents on which the friction process dominantly occurs, evident in topography images of SEM-EDXS. Accurate information about the 
carbonaceous products can be obtained by Raman spectroscopy (RS), even the presence of graphite nano-particles in the friction layer [124,140]. Verma et al. [124] studied the role of the friction layer at high temperatures and found that increasing the disc temperature caused a contraction in secondary plateaus, especially above $350{ }^{\circ} \mathrm{C}$, marking a reduction in iron oxide content at relatively lower temperatures. SEM-EDXS methods for topography and elemental analysis on the micron scale fail when analyzing the outermost surface layer (referred to as "friction film" by some researchers), i.e., the very thin film found on the surface of the friction layer. The interaction depth of electrons is approximately 1-10 $\mu \mathrm{m}$, and thus, most signals may originate from the substrate beneath. FIB imaging, which involves detecting secondary electrons while simultaneously scanning the ion beam, on the other hand, has an interaction depth of ions of the order $10 \mathrm{~nm}$, thus providing the contrast from such thin surface layers $[140,141]$. FIB has also been used as a micro-machining tool to prepare specimens for TEM cross-section specimens, wherein thin lamellae from pads were cut and deposited onto a carbon-coated support TEM grid [137,138,142]. Österle et al. [143] demonstrated through selected area electron diffraction (SAED) patterns that the composition of a friction layer could be different from the parent material by showing the alloyed nanocrystalline barite phase (also found Kukutschová et al. [22] along with $\mathrm{Cu}$ and Fe oxides). Cross-sectional TEM (X-TEM) has the advantage of analyzing the friction layer and its interface with the substrate, although the sample preparation may be rather challenging and the outcome not always satisfactory, considering the limited field of view which is often attained [143]. Obtaining the phase composition of the friction layer through XRD can be difficult owing to the relatively large penetration depth of the incoming X-ray beam, which may penetrate a depth $>1 \mu \mathrm{m}$, i.e., in the same range of which is the thickness of the outer layer [144]). This would result in underestimating the contribution of crystalline phases in the friction layer, particularly from the secondary plateaus [125]. Alemani et al. [125] have cited this to be the reason for not detecting the Fe-oxides, which were certainly there in the secondary plateaus that formed on the surface of brake pads during Dyno-tests. Filip et al. [139] detected the presence of $\mathrm{CuSb}$ and $\mathrm{Cu}_{2} \mathrm{~S}$ phases, produced apparently by the decomposition of $\mathrm{Sb}_{2} \mathrm{~S}_{3}$ and alloying of $\mathrm{Cu}$ with $\mathrm{Sb}$, through combined XRD, SEM, and EDXS analyses.

\subsection{Characterizing Wear Debris}

Wear debris either consists of the torn-off ingredients and micro-chips from the parent materials, or they are milled granular material [134]. Airborne PM consists of a wide range of morphologically and chemically heterogeneous species. It has been proposed that due to mechanical wear, larger particles $\mathrm{PM}_{10}$ and $\mathrm{PM}_{2.5}$, resulting from abrasion and fatigue wear, having irregular morphology with sharper edges, are formed [136]. On the other hand, as temperature increases, oxidative wear tends to dominate with the emission of submicron particles having fewer sharp edges and almost spherical geometry. The outputs from the conventional bulk characterization analyses are averaged results, and may not completely demonstrate the properties of individual particles. Through morphology, we can obtain a first classification of the collected particles, but the morphology is not always sufficient for identifying the source of the particles. Thus, it is essential to emphasize techniques capable of characterizing individual particles. Through single particle analysis (SPA, see Figure 2), it is possible to detect minor elements concentrated in the individual particles. In this perspective, it is always beneficial and recommended to combine bulk analyses with SPA. An elaborative work considering these aspects has been conducted by Verma et al. [90], in which the authors developed an experimental characterization protocol suitable for characterizing particles from the wear tests, with emphasis on the reliability and consistency in the results obtained from low and large scale investigations [18,48].

Though SEM-EDXS cannot yield information regarding the compounds constituting the wear particles, still shape, size and elemental composition can be obtained. XRD, apart from providing information about the brake pad composition, can indicate the relevant phase transformations introduced into the wear debris during testing. EDXS lacks the sensitivity to detect elements present in the wear particles below a minimum concentration, ranging from 0.1 to $10 \%$, depending on the relevant 
atomic number. Similarly, a minimum amount of wear particles is required to produce a sufficiently strong diffracted signal in the case of crystallographic analysis with XRD. Verma et al. [90] could solve the problem with XRD coupled with electron diffraction in TEM, as even a little number of grains were enough to produce reliable crystallographic data. Similarly, Kukutschová et al. [136] proposed the combination of EDXS and proton-induced X-ray emission analysis (PIXE) in their study, featuring a better detectability limit. Thus, we can say that the best results about wear particles can be obtained only when all these characterization tools are used together in a combined way. Obtaining similar or compatible results, for instance, from SEM-EDXS (at lower magnification) and TEM-EDXS (at higher magnification) can improve the reliability of the experiments $[90,125]$.

Regarding TEM, it is one of the most complete characterization tools for nanostructured systems $[145,146]$. Sample preparation can be tricky, and one of the methods is preparing a suspension of wear particles in ethanol (with a preceding set of steps), from which a single drop is deposited onto the TEM gold [90] or $\mathrm{Cu}$ [147] grid. Gold is preferable since provides X-ray emission lines which can be easily separated from the genuine ones, coming from the specimen. TEM can be used for the investigations of grain size and microstructural aspects down to the sub-nanometric scale [148]. Agglomeration/aggregation of particles to form big clusters has been noted through SEM and TEM images $[22,48,89,90,136]$. Often, the agglomerates adhere to the larger particles, being the driving force behind the formation of a large number of agglomerates the minimization of surface energy. TEM study of the wear particles/fragments of the friction layer has often reported a nano-crystalline structure, with a mean grain diameter of $10 \mathrm{~nm}[22,137,138,142]$. The crystalline nature of very fine particles can many times be confirmed by TEM dark-field images. However, although TEM can reveal nanostructures, information at the micrometer scale gets neglected since the sample thickness may be too big for even partial electron transparency. Data from these samples can be obtained through OM and SEM, better if in a correlative way.

The thermal decomposition of resin is a major point of interest in brake wear study. A critical temperature marks the onset of its transformation, accompanied by material softening, with a shift in the wear mechanism from mild to severe wear [124,125,129]. There are variations in the reported critical temperatures: $300^{\circ} \mathrm{C}$ disc [136], $170-190^{\circ} \mathrm{C}$ disc [47], $20{ }^{\circ} \mathrm{C}$ disc [149], $120^{\circ} \mathrm{C}$ disc [150] $160^{\circ} \mathrm{C}$ pin [48]. However, the common meeting point, on which different research groups seem to agree, is that the size distribution of the PM produced after thermal decomposition of the binder, shifts towards smaller fractions, i.e., fine and ultrafine particles. As per some studies, a stepwise increment in ultrafine particles up to six orders of magnitude has been reported $[17,151]$. Thus, thermal characterization is also significant. In this regard, thermal analyses, like differential thermal analysis (DTA) and thermogravimetric analysis (TGA) are of primary importance. The characterization of the degradation products, considering their prominent organic character, maybe profitably carried out using Raman Spectroscopy (RS) and Fourier transform infrared spectroscopy (FTIR), providing insights about the reactions taking place at the lowest temperature treatment. FTIR can be used to study samples that fail due to high luminescence, which renders RS unapplicable. Menapace et al. [129] conducted a combined TGA, RS, and FTIR study to investigate the primary degradation steps of phenolic resins. They observed that above $300{ }^{\circ} \mathrm{C}$, the cross-links begin to break along with the fracture of the methylene bridges. These lead to the release of different terminal groups and the formation of different volatile compounds.

It has been found that the main constituents of the decomposition of phenolic resin in the temperature range $230-450{ }^{\circ} \mathrm{C}$ are: $\mathrm{H}_{2} \mathrm{O}$ and $\mathrm{CO}_{2}[129,152,153]$, corresponding to a major mass loss. A minor mass loss at a lower temperature range $50-200{ }^{\circ} \mathrm{C}$ has been also noted, likely due to the evaporation/oxidation of organic compounds [124,154,155]. Peikertová et al. [156] included RS in their analyses for effective detection and characterization of the different oxidized forms of iron, i.e., $\mathrm{Fe}_{2} \mathrm{O}_{3}$ and $\mathrm{Fe}_{3} \mathrm{O}_{4}$, in the wear debris, and the presence of other phases like calcite. Thus, RS has a lot of significance in wear debris characterization, as it can be used for phase identification, being particularly useful in distinguishing forms of carbon: amorphous carbon and graphite, even with intermediate degrees of structural disorder $[156,157]$. Data concerning the organic constituents released during brake wear are 
limited, as the majority of studies have focused on the inorganic components of wear debris. Carbon is expected to be present in brake wear particles in large quantities because of the usage of graphite as a friction modifier, in addition to the organic resins as adhesive. A few studies have attempted to measure the contribution of elemental carbon (EC) and organic carbon (OC) specifically from brake pads. Zhao et al. [147] estimated the EC/OC ratio as $0.086-0.28$ in the case of aged pads, and similar values were obtained in the case of new brake pads, as the ratio was found to vary in the range $0.05-0.29[158,159]$. Gas chromatography coupled to mass spectrometry (GC/MS) of the non-airborne wear debris has detected up to 49 compounds with a high probability of mass spectrum conformity, including polycyclic aromatic hydrocarbons, which are well known hazardous substances $[126,160]$.

Eventually, Table 7 highlights the major characterization tools typically used for analyzing the friction layer and wear debris.

Table 7. Overview of different characterization tools used for wear debris and friction layer analysis.

\begin{tabular}{|c|c|c|}
\hline Characterization Method & References & Major Functions \\
\hline SEM-EDXS & 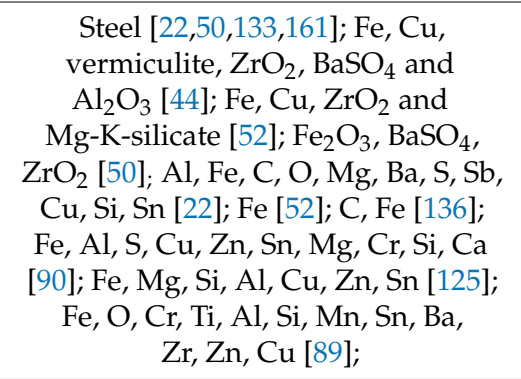 & $\begin{array}{l}\text { Morphology and composition of } \\
\text { single particles at lower } \\
\text { magnification; Chemical } \\
\text { composition of the substrate and } \\
\text { thick friction layer }(>1 \mu \mathrm{m})\end{array}$ \\
\hline TEM-EDXS & $\begin{array}{c}\mathrm{Cu}, \mathrm{Fe}, \mathrm{Ba}, \mathrm{O} \text { [132]; C (chaoite) [139]; } \\
\mathrm{Cu}, \mathrm{Fe}, \mathrm{O}, \mathrm{S}, \mathrm{Ni}, \mathrm{Zn}, \mathrm{C}[141] ; \mathrm{Fe}, \mathrm{Mg}, \\
\mathrm{Al}, \mathrm{Si} \text { [125]; } \mathrm{Fe}, \mathrm{Al}, \mathrm{S}, \mathrm{Cu}, \mathrm{Zn}, \mathrm{Sn}, \mathrm{Mg}, \\
\mathrm{Cr}, \mathrm{Si}, \mathrm{Ca}[90] ; \mathrm{Fe}, \mathrm{O}, \mathrm{Zn}, \mathrm{Cu}, \mathrm{Ca}, \mathrm{S} \text { and } \\
\mathrm{Si}[138] ; \mathrm{Cu}, \mathrm{Fe}, \mathrm{C}, \mathrm{Al}, \mathrm{Si}, \mathrm{Zn}[142] ; \mathrm{Fe}, \\
\mathrm{O}, \mathrm{Cu}, \mathrm{Si}, \mathrm{Mg}[137]\end{array}$ & $\begin{array}{l}\text { Morphology and composition } \\
\text { of single particles at } \\
\text { higher magnification; } \\
\text { Analyzing thin films }\end{array}$ \\
\hline SAED & $\begin{array}{c}\mathrm{Cu}, \mathrm{Fe}_{3} \mathrm{O}_{4}[132] ; \mathrm{Fe}_{3} \mathrm{O}_{4} \text {, spinels [138]; } \\
\mathrm{Fe}_{3} \mathrm{O}_{4}, \alpha \text {-iron [137], } \mathrm{Cu} / \text { brass, } \mathrm{CuFeO}_{2} \\
\mathrm{Fe}_{2} \mathrm{O}_{3}, \mathrm{Cu}_{2} \mathrm{O}, \mathrm{Fe}_{3} \mathrm{O}_{4}[141] ; \mathrm{BaSO}_{4} \\
\mathrm{Fe}_{2} \mathrm{O}_{3}, \mathrm{Cu}_{2} \mathrm{O}, \mathrm{FeO}, \mathrm{Cu}, \text { graphite [22]; } \\
\gamma-\mathrm{Fe}_{2} \mathrm{O}_{3}, \mathrm{FeO} . \mathrm{Fe}_{2} \mathrm{O}_{3}, \mathrm{C} \text { [136]; } \mathrm{BaSO}_{4} \\
\mathrm{Sb}_{2} \mathrm{~S}_{3} \text {, vermiculite, quartz, } \\
\text { iron oxides [143]; } \mathrm{Fe}_{2} \mathrm{O}_{3}, \mathrm{Fe}_{3} \mathrm{O}_{4} \\
\mathrm{MgO} \text { [90]; } \mathrm{Fe}_{2} \mathrm{O}_{3}, \mathrm{Fe}_{2} \mathrm{Fe}_{3} \mathrm{O}_{4}[125]\end{array}$ & Crystallographic analysis \\
\hline XRD & $\begin{array}{c}\text { Graphite, } \mathrm{Cu} \mathrm{Zn} \mathrm{Fe} \text { Oxides, } \mathrm{Fe}, \\
\mathrm{Cu}, \mathrm{Zn}[125] ; \mathrm{C}, \mathrm{ZrSiO}_{4}, \mathrm{Fe}, \mathrm{Cu}, \\
\mathrm{Sb}_{2} \mathrm{~S}_{3} \text {,vermiculite, } \mathrm{MoS}_{2}, \mathrm{Cu} \text {-oxides, } \\
\mathrm{Fe}-\text { oxides [139]; } \mathrm{FeO}, \mathrm{Fe}, \mathrm{Fe}_{2} \mathrm{O}_{3}, \mathrm{MgO}, \\
\mathrm{ZnO}, \mathrm{Cu}[90] ; \mathrm{Fe}_{2} \mathrm{O}_{3} \text { and } \mathrm{Fe}_{3} \mathrm{O}_{4} \\
\mathrm{ZrSiO}_{4}, \mathrm{Sb}_{2} \mathrm{O}_{5}, \mathrm{Sb}_{2} \mathrm{Fe}, \mathrm{BaSO}_{4} \\
\left(\mathrm{Mg}_{0.064} \mathrm{Ca}_{0.936}\right) \mathrm{CO}_{3}[157]\end{array}$ & Phase composition \\
\hline RS & $\begin{array}{c}\text { Carbon black, graphite [136]; } \\
\text { amorphous carbon [129]; } \mathrm{CaCO}_{3}, \\
\mathrm{Fe}_{2} \mathrm{O}_{3}, \mathrm{Fe}_{3} \mathrm{O}_{4}, \mathrm{SiO}_{2}, \text { labradorite, } \\
\text { carbon black [156]; graphite, } \\
\mathrm{Fe}_{3} \mathrm{O}_{4} \text { [140]; graphite(crystalline } \\
\text { and disordered) and } \\
\text { amorphous carbon [124]; } \mathrm{BaSO}_{4}, \\
\mathrm{CaCO}_{3}, \mathrm{Fe}_{2} \mathrm{O}_{3}, \mathrm{Fe}_{3} \mathrm{O}_{4}, \mathrm{MoS}_{2}, \mathrm{C} \\
\text { (amorphous and graphite) }[157]\end{array}$ & $\begin{array}{l}\text { Carbonaceous pad components } \\
\text { and wear products }\end{array}$ \\
\hline
\end{tabular}




\section{Conclusions and Perspectives}

In this review paper, we presented several aspects concerning the characterization approach to wear particles coming from disc brake systems. This is an interesting issue not only as concerns the environment and health impact but also for the design of new materials brake materials, both pads and discs.

In fact, numerous studies have confirmed that the wear of the brake pad-disc unit is a potential source of airborne PM. Driving speed, applied pressure, constituents of the brake materials, weather, road surface-all play their role as concerns the extent of wear and the nature of emissions. The focus has to be on limiting/eliminating the harmful constituents found in existing brake pad formulations, in line with the idea of the development of novel eco-friendly pads. At the same time, disc treatments and coatings are definitely important for reducing emissions.

Usage of different test standards to generate, measure and characterize the wear products leads to a higher degree of complexity, rendering the data not always easily comparable. For instance, studies that include number distribution for quantification of wear particles could note the presence of the finest particles $(<1 \mu \mathrm{m})$ in large quantities. This could be a missing aspect for studies relying on mass distribution only, leading to an underestimation of such particles, whose mass contribution is extremely low.

PoD and dynamometer test rigs have led to the development of the field, with the possibility of size-resolved sampling of the airborne particles. However, all particles generating techniques suffer from limitations. On dynamometers, it is not possible to replicate transient speed conditions and the effects of weather and real road driving. Some studies which tested the same materials on both the setups could better explain particle generation. Size resolved sampling of airborne particles facilitates better decision making as concerns the characterization tools to be used.

Considering the complexities of the wear mechanism involved, relying on a single selected characterization tool may yield unsatisfactory results. Multi-analytical protocols are therefore very much recommended. In this regard, SEM-EDXS, TEM-EDXS coupled with SAED have added advantages and facilitate single particle analysis, all of them being intrinsically multi-purpose experimental tools.

So far, the majority of the studies have been concentrated on PM, i.e., condensed phase, emission. In perspective, gaseous emissions should be investigated more deeply, in view of their important implications.

Author Contributions: A.S. and S.G. bibliographic survey: A.S. and S.G.; drafting the original manuscript: A.S. and S.G.; critical revision of the whole manuscript: All Authors; insight into specific microstructural and crystallographic results: G.I. and C.M.; funding acquisition: S.G.; supervision: A.S. and S.G. All authors have agreed on the submitted version of the manuscript.

Funding: The research has received financial support by the EIT-Raw Materials through the EU Project: ECOPADS-Eliminating COpper from brake PADS \& recycling.-n. 17182.

Acknowledgments: The Authors would like to thank Guido Perricone (Brembo SpA) and Giovanni Straffelini (University of Trento) for the useful discussions on all matters considered in the present paper.

Conflicts of Interest: The authors declare no conflict of interest.

\section{References}

1. Health Effects Institute. State of Global Air 2019. Available online: https://www.stateofglobalair.org/report (accessed on 4 August 2020).

2. Kumar, P.; Pirjola, L.; Ketzel, M.; Harrison, R.M. Nanoparticle emissions from 11 non-vehicle exhaust sources-A review. Atmos. Environ. 2013, 67, 252-277. [CrossRef]

3. Thorpe, A.; Harrison, R.M. Sources and properties of non-exhaust particulate matter from road traffic: A review. Sci. Total Environ. 2008, 400, 270-282. [CrossRef]

4. Andersen, Z.J.; Wahlin, P.; Raaschou-Nielsen, O.; Ketzel, M.; Scheike, T.; Loft, S. Size distribution and total number concentration of ultrafine and accumulation mode particles and hospital admissions in children and the elderly in Copenhagen, Denmark. Occup. Environ. Med. 2008, 65, 458-466. [CrossRef] [PubMed] 
5. Sun, Q.; Hong, X.; Wold, L.E. Cardiovascular Effects of Ambient Particulate Air Pollution Exposure. Circulation 2010, 121, 2755-2765. [CrossRef] [PubMed]

6. Grigoratos, T.; Martini, G. Brake wear particle emissions: A review. Environ. Sci. Pollut. Res. 2015, 22, 2491-2504. [CrossRef]

7. Gu, J.; Pitz, M.; Schnelle-Kreis, J.; Diemer, J.; Reller, A.; Zimmermann, R.; Soentgen, J.; Stoelzel, M.; Wichmann, H.-E.; Peters, A.; et al. Source apportionment of ambient particles: Comparison of positive matrix factorization analysis applied to particle size distribution and chemical composition data. Atmos. Environ. 2011, 45, 1849-1857. [CrossRef]

8. Morawska, L.; Thomas, S.; Jamriska, M.; Johnson, G. The modality of particle size distributions of environmental aerosols. Atmos. Environ. 1999, 33, 4401-4411. [CrossRef]

9. Beddows, D.C.S.; Dall'Osto, M.; Olatunbosun, O.A.; Harrison, R.M. Detection of brake wear aerosols by aerosol time-of-flight mass spectrometry. Atmos. Environ. 2016, 129, 167-175. [CrossRef]

10. Adamiec, E.; Jarosz-Krzemińska, E.; Wieszała, R. Heavy metals from non-exhaust vehicle emissions in urban and motorway road dusts. Environ. Monit. Assess. 2016, 188, 369. [CrossRef]

11. Amato, F.; Cassee, F.R.; Denier van der Gon, H.A.C.; Gehrig, R.; Gustafsson, M.; Hafner, W.; Harrison, R.M.; Jozwicka, M.; Kelly, F.J.; Moreno, T.; et al. Urban air quality: The challenge of traffic non-exhaust emissions. J. Hazard. Mater. 2014, 275, 31-36. [CrossRef]

12. Peikertova, P.; Filip, P. Influence of the Automotive Brake Wear Debris on the Environment-A Review of Recent Research. SAE Int. J. Mater. Manuf. 2016, 9, 133-146. [CrossRef]

13. Straffelini, G.; Maines, L. The relationship between wear of semimetallic friction materials and pearlitic cast iron in dry sliding. Wear 2013, 307, 75-80. [CrossRef]

14. Ketzel, M.; Omstedt, G.; Johansson, C.; Düring, I.; Pohjola, M.; Oettl, D.; Gidhagen, L.; Wåhlin, P.; Lohmeyer, A.; Haakana, M.; et al. Estimation and validation of PM2.5/PM10 exhaust and non-exhaust emission factors for practical street pollution modelling. Atmos. Environ. 2007, 41, 9370-9385. [CrossRef]

15. Perricone, G.; Alemani, M.; Wahlström, J.; Olofsson, U. A proposed driving cycle for brake emissions investigation for test stand. Proc. Inst. Mech. Eng. Part J. Automob. Eng. 2020, 234, 122-135. [CrossRef]

16. Farrow, K.; Oueslati, W. Non-Exhaust Emissions from Road Transport. Causes, Consequences and Policy Responses; Environment directorate, Environment policy committee, OECD: Paris, France, 2020.

17. Alemani, M.; Nosko, O.; Metinoz, I.; Olofsson, U. A Study on Emission of Airborne Wear Particles from Car Brake Friction Pairs. SAE Int. J. Mater. Manuf. 2016, 9, 147-157. [CrossRef]

18. Menapace, C.; Mancini, A.; Federici, M.; Straffelini, G.; Gialanella, S. Characterization of airborne wear debris produced by brake pads pressed against HVOF-coated discs. Frict. Heidelb. 2020, 8, 421-432. [CrossRef]

19. Harrison, R.M.; Jones, A.M.; Gietl, J.; Yin, J.; Green, D.C. Estimation of the Contributions of Brake Dust, Tire Wear, and Resuspension to Nonexhaust Traffic Particles Derived from Atmospheric Measurements. Environ. Sci. Technol. 2012, 46, 6523-6529. [CrossRef]

20. Olofsson, U.; Olander, L.; Jansson, A. A Study of Airborne Wear Particles Generated From a Sliding Contact. J. Tribol. 2009, 131, 044503. [CrossRef]

21. Straffelini, G.; Ciudin, R.; Ciotti, A.; Gialanella, S. Present knowledge and perspectives on the role of copper in brake materials and related environmental issues: A critical assessment. Environ. Pollut. 2015, 207, 211-219. [CrossRef]

22. Kukutschová, J.; Roubíček, V.; Malachová, K.; Pavlíčková, Z.; Holuša, R.; Kubačková, J.; Mička, V.; MacCrimmon, D.; Filip, P. Wear mechanism in automotive brake materials, wear debris and its potential environmental impact. Wear 2009, 267, 807-817. [CrossRef]

23. Roubicek, V.; Raclavska, H.; Juchelkova, D.; Filip, P. Wear and environmental aspects of composite materials for automotive braking industry. Wear 2008, 265, 167-175. [CrossRef]

24. Sanders, P.G.; Xu, N.; Dalka, T.M.; Maricq, M.M. Airborne Brake Wear Debris: Size Distributions, Composition, and a Comparison of Dynamometer and Vehicle Tests. Environ. Sci. Technol. 2003, 37, 4060-4069. [CrossRef] [PubMed]

25. Kř́stková, M.; Weiss, Z.; Filip, P. Hydration properties of vermiculite in phenolic resin friction composites. Appl. Clay Sci. 2004, 25, 229-236. [CrossRef]

26. Wahlström, J.; Söderberg, A.; Olander, L.; Olofsson, U.; Jansson, A. Airborne wear particles from passenger car disc brakes: A comparison of measurements from field tests, a disc brake assembly test stand, and a pin-on-disc machine. Proc. Inst. Mech. Eng. Part J J. Eng. Tribol. 2010, 224, 179-188. [CrossRef] 
27. Cha, S.; Carter, P.; Bradow, R.L. Simulation of Automobile Brake Wear Dynamics and Estimation of Emissions. SAE Trans. 1983, 92, 502-522.

28. Garg, B.D.; Cadle, S.H.; Mulawa, P.A.; Groblicki, P.J.; Laroo, C.; Parr, G.A. Brake Wear Particulate Matter Emissions. Environ. Sci. Technol. 2000, 34, 4463-4469. [CrossRef]

29. Iijima, A.; Sato, K.; Yano, K.; Tago, H.; Kato, M.; Kimura, H.; Furuta, N. Particle size and composition distribution analysis of automotive brake abrasion dusts for the evaluation of antimony sources of airborne particulate matter. Atmos. Environ. 2007, 41, 4908-4919. [CrossRef]

30. Perricone, G.; Alemani, M.; Metinöz, I.; Matějka, V.; Wahlström, J.; Olofsson, U. Towards the ranking of airborne particle emissions from car brakes - a system approach. Proc. Inst. Mech. Eng. Part J. Automob. Eng. 2017, 231, 781-797. [CrossRef]

31. Thorpe, A.J.; Harrison, R.M.; Boulter, P.G.; McCrae, I.S. Estimation of particle resuspension source strength on a major London Road. Atmos. Environ. 2007, 41, 8007-8020. [CrossRef]

32. Sarnat, J.A.; Schwartz, J.; Suh, H.H. Fine particulate air pollution and mortality in 20 U.S. cities. N. Engl. J. Med. 2001, 344, 1253-1254. [CrossRef]

33. Iii, C.A.P.; Burnett, R.T.; Thun, M.J.; Calle, E.E.; Krewski, D.; Ito, K.; Thurston, G.D. Lung Cancer, Cardiopulmonary Mortality, and Long-term Exposure to Fine Particulate Air Pollution. JAMA 2002, 287, 1132-1141. [CrossRef]

34. Ghio, A.J. Disruption of iron homeostasis and lung disease. Biochim. Biophys. Acta BBA Gen. Subj. 2009, 1790, 731-739. [CrossRef]

35. Ghio, A.J.; Silbajoris, R.; Carson, J.L.; Samet, J.M. Biologic effects of oil fly ash. Environ. Health Perspect. 2002, 110, 89-94. [CrossRef] [PubMed]

36. Menapace, C.; Leonardi, M.; Perricone, G.; Bortolotti, M.; Straffelini, G.; Gialanella, S. Pin-on-disc study of brake friction materials with ball-milled nanostructured components. Mater. Des. 2017, 115, 287-298. [CrossRef]

37. Chan, D.; Stachowiak, G.W. Review of automotive brake friction materials. Proc. Inst. Mech. Eng. Part J. Automob. Eng. 2004, 218, 953-966. [CrossRef]

38. Österle, W.; Dmitriev, A.I. The Role of Solid Lubricants for Brake Friction Materials. Lubricants 2016, 4, 5. [CrossRef]

39. Wahid, S.M.S. Automotive brake wear: A review. Environ. Sci. Pollut. Res. 2018, 25, 174-180. [CrossRef] [PubMed]

40. Kumar, V.V.; Kumaran, S.S. Friction material composite: Types of brake friction material formulations and effects of various ingredients on brake performance-a review. Mater. Res. Express 2019, 6, 082005. [CrossRef]

41. Satapathy, B.K.; Bijwe, J. Analysis of simultaneous influence of operating variables on abrasive wear of phenolic composites. Wear 2002, 253, 787-794. [CrossRef]

42. Smales, H. Friction Materials-Black Art or Science? Proc. Inst. Mech. Eng. Part J. Automob. Eng. 1995, 209, 151-157. [CrossRef]

43. Newcomb, T.P.; Spurr, R.T. Friction materials for brakes. Tribology 1971, 4, 75-81. [CrossRef]

44. Verma, P.C.; Menapace, L.; Bonfanti, A.; Ciudin, R.; Gialanella, S.; Straffelini, G. Braking pad-disc system: Wear mechanisms and formation of wear fragments. Wear 2015, 322-323, 251-258. [CrossRef]

45. Kukutschová, J.; Filip, P. Chapter 6-Review of Brake Wear Emissions: A Review of Brake Emission Measurement Studies: Identification of Gaps and Future Needs. In Non-Exhaust Emissions; Amato, F., Ed.; Academic Press: Cambridge, MA, USA, 2018; pp. 123-146. ISBN 978-0-12-811770-5.

46. Sellami, A.; Kchaou, M.; Elleuch, R.; Cristol, A.-L.; Desplanques, Y. Study of the interaction between microstructure, mechanical and tribo-performance of a commercial brake lining material. Mater. Des. 2014, 59, 84-93. [CrossRef]

47. Alemani, M.; Wahlström, J.; Olofsson, U. On the influence of car brake system parameters on particulate matter emissions. Wear 2018, 396-397, 67-74. [CrossRef]

48. Perricone, G.; Matějka, V.; Alemani, M.; Valota, G.; Bonfanti, A.; Ciotti, A.; Olofsson, U.; Söderberg, A.; Wahlström, J.; Nosko, O.; et al. A concept for reducing PM10 emissions for car brakes by 50\%. Wear 2018, 396-397, 135-145. [CrossRef]

49. Kukutschová, J.; Roubíček, V.; Mašláň, M.; Jančík, D.; Slovák, V.; Malachová, K.; Pavlíčková, Z.; Filip, P. Wear performance and wear debris of semimetallic automotive brake materials. Wear 2010, 268, 86-93. [CrossRef]

50. Federici, M.; Alemani, M.; Menapace, C.; Gialanella, S.; Perricone, G.; Straffelini, G. A critical comparison of dynamometer data with pin-on-disc data for the same two friction material pairs-A case study. Wear 2019, 424-425, 40-47. [CrossRef] 
51. Straffelini, G. Friction and Wear: Methodologies for Design and Control; Springer Tracts in Mechanical Engineering: Cham, Switzerland; Springer International Publishing: Cham, Switzerland, 2015; ISBN 978-3-319-05893-1.

52. Federici, M.; Gialanella, S.; Leonardi, M.; Perricone, G.; Straffelini, G. A preliminary investigation on the use of the pin-on-disc test to simulate off-brake friction and wear characteristics of friction materials. Wear 2018, 410-411, 202-209. [CrossRef]

53. Cho, M.H.; Kim, S.J.; Kim, D.; Jang, H. Effects of ingredients on tribological characteristics of a brake lining: An experimental case study. Wear 2005, 258, 1682-1687. [CrossRef]

54. Neis, P.D.; Ferreira, N.F.; Fekete, G.; Matozo, L.T.; Masotti, D. Towards a better understanding of the structures existing on the surface of brake pads. Tribol. Int. 2017, 105, 135-147. [CrossRef]

55. Wahlström, J.; Söderberg, A.; Olander, L.; Jansson, A.; Olofsson, U. A pin-on-disc simulation of airborne wear particles from disc brakes. Wear 2010, 268, 763-769. [CrossRef]

56. Menapace, C.; Leonardi, M.; Matějka, V.; Gialanella, S.; Straffelini, G. Dry sliding behavior and friction layer formation in copper-free barite containing friction materials. Wear 2018, 398-399, 191-200. [CrossRef]

57. Aranganathan, N.; Bijwe, J. Development of copper-free eco-friendly brake-friction material using novel ingredients. Wear 2016, 352-353, 79-91. [CrossRef]

58. Straffelini, G.; Verma, P.C.; Metinoz, I.; Ciudin, R.; Perricone, G.; Gialanella, S. Wear behavior of a low metallic friction material dry sliding against a cast iron disc: Role of the heat-treatment of the disc. Wear 2016, 348-349, 10-16. [CrossRef]

59. Sundarkrishnaa, K.L. Friction Material Composites: Copper-/Metal-Free Material Design Perspective; Springer: Berlin/Heidelberg, Germany, 2015; ISBN 978-3-319-14069-8.

60. Riahi, A.R.; Alpas, A.T. Wear map for grey cast iron. Wear 2003, 255, 401-409. [CrossRef]

61. Dizdar, S.; Lyu, Y.; Lampa, C.; Olofsson, U. Grey Cast Iron Brake Discs Laser Cladded with Nickel-Tungsten Carbide-Friction, Wear and Airborne Wear Particle Emission. Atmosphere 2020, 11, 621. [CrossRef]

62. Djafri, M.; Bouchetara, M.; Busch, C.; Weber, S. Effects of humidity and corrosion on the tribological behaviour of the brake disc materials. Wear 2014, 321, 8-15. [CrossRef]

63. Noh, H.J.; Jang, H. Friction instability induced by iron and iron oxides on friction material surface. Wear 2018, 400-401, 93-99. [CrossRef]

64. Blau, P.J.; Meyer, H.M. Characteristics of wear particles produced during friction tests of conventional and unconventional disc brake materials. Wear 2003, 255, 1261-1269. [CrossRef]

65. Grieve, D.G.; Barton, D.C.; Crolla, D.A.; Buckingham, J.T. Design of a lightweight automotive brake disc using finite element and Taguchi techniques. Proc. Inst. Mech. Eng. Part J. Automob. Eng. 1998, 212, 245-254. [CrossRef]

66. Bensalah, W.; Elleuch, K.; Feki, M.; DePetris-Wery, M.; Ayedi, H.F. Comparative study of mechanical and tribological properties of alumina coatings formed on aluminium in various conditions. Mater. Des. 2009, 30, 3731-3737. [CrossRef]

67. Bolelli, G.; Cannillo, V.; Lusvarghi, L.; Manfredini, T. Wear behaviour of thermally sprayed ceramic oxide coatings. Wear 2006, 261, 1298-1315. [CrossRef]

68. Alnaqi, A.A.; Kosarieh, S.; Barton, D.C.; Brooks, P.C.; Shrestha, S. Material characterisation of lightweight disc brake rotors. Proc. Inst. Mech. Eng. Part J. Mater. Des. Appl. 2018, 232, 555-565. [CrossRef]

69. Thornton, R.; Slatter, T.; Jones, A.H.; Lewis, R. The effects of cryogenic processing on the wear resistance of grey cast iron brake discs. Wear 2011, 271, 2386-2395. [CrossRef]

70. Nadig, D.S.; Shivakumar, P.; Anoop, S.; Chinmay, K.; Divine, P.V.; Harsha, H.P. Effects of cryogenic treatment on the wear properties of brake discs. IOP Conf. Ser. Mater. Sci. Eng. 2017, 171, 012152. [CrossRef]

71. Haseeb, A.S.M.A.; Islam, M.A.; Bepari, M.M.A. Tribological behaviour of quenched and tempered, and austempered ductile iron at the same hardness level. Wear 2000, 244, 15-19. [CrossRef]

72. Federici, M.; Menapace, C.; Moscatelli, A.; Gialanella, S.; Straffelini, G. Pin-on-disc study of a friction material dry sliding against $\mathrm{HVOF}$ coated discs at room temperature and $300{ }^{\circ} \mathrm{C}$. Tribol. Int. 2017, 115, 89-99. [CrossRef]

73. Anderson, A.E.; Gratch, S.; Hayes, H.P. A New Laboratory Friction and Wear Test for the Characterization of Brake Linings; SAE Technical Paper; SAE International: Warrendale, PA, USA, 1967; p. 670079.

74. Sanders, P.G.; Dalka, T.M.; Basch, R.H. A reduced-scale brake dynamometer for friction characterization. Tribol. Int. 2001, 34, 609-615. [CrossRef]

75. Perzborn, N.; Agudelo, C.; Ostermeyer, G.P. On Similarities and Differences of Measurements on Inertia Dynamometer and Scale Testing Tribometer for Friction Coefficient Evaluation. SAE Int. J. Mater. Manuf. 2015, 8, 104-117. [CrossRef] 
76. Burkman, A.J.; Hishley, F.H. Laboratory Evaluation of Brake Lining Materials; SAE Technical Paper; SAE International: Warrendale, PA, USA, 1967; p. 670510.

77. Hagino, H.; Oyama, M.; Sasaki, S. Laboratory testing of airborne brake wear particle emissions using a dynamometer system under urban city driving cycles. Atmos. Environ. 2016, 131, 269-278. [CrossRef]

78. Wahlström, J.; Söderberg, A.; Olander, L.; Olofsson, U. A disc brake test stand for measurement of airborne wear particles. Lubr. Sci. 2009, 21, 241-252. [CrossRef]

79. Nosko, O.; Olofsson, U. Quantification of ultrafine airborne particulate matter generated by the wear of car brake materials. Wear 2017, 374-375, 92-96. [CrossRef]

80. Sanders, P.G.; Dalka, T.M.; Xu, N.; Maricq, M.M.; Basch, R.H. Brake Dynamometer Measurement of Airborne Brake Wear Debris. SAE Trans. 2002, 111, 1693-1699.

81. Hagino, H.; Oyama, M.; Sasaki, S. Airborne brake wear particle emission due to braking and accelerating. Wear 2015, 334-335, 44-48. [CrossRef]

82. Chasapidis, L.; Grigoratos, T.; Zygogianni, A.; Tsakis, A.; Konstandopoulos, A.G. Study of Brake Wear Particle Emissions of a Minivan on a Chassis Dynamometer. Emiss. Control Sci. Technol. 2018, 4, 271-278. [CrossRef]

83. zum Hagen, F.H.F.; Mathissen, M.; Grabiec, T.; Hennicke, T.; Rettig, M.; Grochowicz, J.; Vogt, R.; Benter, T. Study of Brake Wear Particle Emissions: Impact of Braking and Cruising Conditions. Environ. Sci. Technol. 2019, 53, 5143-5150. [CrossRef]

84. zum Hagen, F.H.F.; Mathissen, M.; Grabiec, T.; Hennicke, T.; Rettig, M.; Grochowicz, J.; Vogt, R.; Benter, T. On-road vehicle measurements of brake wear particle emissions. Atmos. Environ. 2019, 217, 116943. [CrossRef]

85. Perricone, G.; Wahlström, J.; Olofsson, U. Towards a test stand for standardized measurements of the brake emissions. Proc. Inst. Mech. Eng. Part J. Automob. Eng. 2016, 230, 1521-1528. [CrossRef]

86. Bijwe, J. Composites as friction materials: Recent developments in non-asbestos fiber reinforced friction materials-A review. Polym. Compos. 1997, 18, 378-396. [CrossRef]

87. Straffelini, G.; Pellizzari, M.; Molinari, A. Influence of load and temperature on the dry sliding behaviour of Al-based metal-matrix-composites against friction material. Wear 2004, 256, 754-763. [CrossRef]

88. Söderberg, A.; Wahlström, J.; Olander, L.; Jansson, A.; Olofsson, U. On Airborne Wear Particles Emissions of Commercial Disc Brake Materials-A Pin on Disc Simulation. Available online: http://urn.kb.se/resolve?urn= urn:nbn:se:kth:diva-37246 (accessed on 21 September 2020).

89. Wahlström, J.; Gventsadze, D.; Olander, L.; Kutelia, E.; Gventsadze, L.; Tsurtsumia, O.; Olofsson, U. A pin-on-disc investigation of novel nanoporous composite-based and conventional brake pad materials focussing on airborne wear particles. Tribol. Int. 2011, 44, 1838-1843. [CrossRef]

90. Verma, P.C.; Alemani, M.; Gialanella, S.; Lutterotti, L.; Olofsson, U.; Straffelini, G. Wear debris from brake system materials: A multi-analytical characterization approach. Tribol. Int. 2016, 94, 249-259. [CrossRef]

91. Mosleh, M.; Blau, P.J.; Dumitrescu, D. Characteristics and morphology of wear particles from laboratory testing of disk brake materials. Wear 2004, 256, 1128-1134. [CrossRef]

92. Lyu, Y.; Leonardi, M.; Wahlström, J.; Gialanella, S.; Olofsson, U. Friction, wear and airborne particle emission from Cu-free brake materials. Tribol. Int. 2020, 141, 105959. [CrossRef]

93. Viana, M.; Kuhlbusch, T.A.J.; Querol, X.; Alastuey, A.; Harrison, R.M.; Hopke, P.K.; Winiwarter, W.; Vallius, M.; Szidat, S.; Prévôt, A.S.H.; et al. Source apportionment of particulate matter in Europe: A review of methods and results. J. Aerosol Sci. 2008, 39, 827-849. [CrossRef]

94. Santoso, M.; Lestiani, D.D.; Markwitz, A. Characterization of airborne particulate matter collected at Jakarta roadside of an arterial road. J. Radioanal. Nucl. Chem. 2013, 297, 165-169. [CrossRef]

95. Amato, F. Non-Exhaust Emissions: An Urban Air Quality Problem for Public Health. In Impact and Mitigation Measures; Academic Press: Cambridge, MA, USA, 2018; ISBN 978-0-12-811751-4.

96. Harrison, R.M.; Beddows, D.C.S.; Dall'Osto, M. PMF Analysis of Wide-Range Particle Size Spectra Collected on a Major Highway. Environ. Sci. Technol. 2011, 45, 5522-5528. [CrossRef]

97. Hopke, P.K. Review of receptor modeling methods for source apportionment. J. Air Waste Manag. Assoc. 1995 2016, 66, 237-259. [CrossRef]

98. Union, P.O. of the E. European Guide on Air Pollution Source Apportionment with Receptor Models: Revised Version 2019. Available online: http://op.europa.eu/en/publication-detail/-/publication/b83f25e6-b273-11e99d01-01aa75ed71a1/language-en (accessed on 21 September 2020). 
99. Galvão, E.S.; D'Azeredo Orlando, M.T.; Santos, J.M.; Lima, A.T. Uncommon chemical species in PM2.5 and PM10 and its potential use as industrial and vehicular markers for source apportionment studies. Chemosphere 2020, 240, 124953. [CrossRef]

100. Cho, M.H.; Ju, J.; Kim, S.J.; Jang, H. Tribological properties of solid lubricants (graphite, Sb2S3, MoS2) for automotive brake friction materials. Wear 2006, 260, 855-860. [CrossRef]

101. Lee, W.K.; Rhee, T.H.; Kim, H.S.; Jang, H. Effects of antimony trisulfide (Sb2S3) on sliding friction of automotive brake friction materials. Met. Mater. Int. 2013, 19, 1101-1107. [CrossRef]

102. Bettella, M.; Harrison, M.F.; Sharp, R.S. Investigation of automotive creep groan noise with a distributed-source excitation technique. J. Sound Vib. 2002, 255, 531-547. [CrossRef]

103. Varrica, D.; Bardelli, F.; Dongarrà, G.; Tamburo, E. Speciation of Sb in airborne particulate matter, vehicle brake linings, and brake pad wear residues. Atmos. Environ. 2013, 64, 18-24. [CrossRef]

104. Yan, G.; Mao, L.; Jiang, B.; Chen, X.; Gao, Y.; Chen, C.; Li, F.; Chen, L. The source apportionment, pollution characteristic and mobility of $\mathrm{Sb}$ in roadside soils affected by traffic and industrial activities. J. Hazard. Mater. 2020, 384, 121352. [CrossRef]

105. Budai, P.; Clement, A. Spatial distribution patterns of four traffic-emitted heavy metals in urban road dust and the resuspension of brake-emitted particles: Findings of a field study. Transp. Res. Part Transp. Environ. 2018, 62, 179-185. [CrossRef]

106. Iijima, A.; Sato, K.; Yano, K.; Kato, M.; Kozawa, K.; Furuta, N. Emission Factor for Antimony in Brake Abrasion Dusts as One of the Major Atmospheric Antimony Sources. Environ. Sci. Technol. 2008, 42, 2937-2942. [CrossRef]

107. Pant, P.; Baker, S.J.; Shukla, A.; Maikawa, C.; Godri Pollitt, K.J.; Harrison, R.M. The PM10 fraction of road dust in the UK and India: Characterization, source profiles and oxidative potential. Sci. Total Environ. 2015, 530-531, 445-452. [CrossRef]

108. Schauer, J.J.; Lough, G.C.; Shafer, M.M.; Christensen, W.F.; Arndt, M.F.; DeMinter, J.T.; Park, J.S. Characterization of metals emitted from motor vehicles. Res. Rep. Health Eff. Inst. 2006, 133, 1-76.

109. Hulskotte, J.H.J.; Roskam, G.D.; Denier van der Gon, H.A.C. Elemental composition of current automotive braking materials and derived air emission factors. Atmos. Environ. 2014, 99, 436-445. [CrossRef]

110. Faullant, P. Particle size effects of tin sulfides in disc brake pads. SAE Tech. Pap. 2002, undefinedundefined.[CrossRef]

111. Copper-Free Brake Initiative. Available online: https://www.epa.gov/npdes/copper-free-brake-initiative (accessed on 8 September 2020).

112. Wåhlin, P.; Berkowicz, R.; Palmgren, F. Characterisation of traffic-generated particulate matter in Copenhagen. Atmos. Environ. 2006, 40, 2151-2159. [CrossRef]

113. Österle, W.; Deutsch, C.; Gradt, T.; Orts-Gil, G.; Schneider, T.; Dmitriev, A.I. Tribological screening tests for the selection of raw materials for automotive brake pad formulations. Tribol. Int. 2014, 73, 148-155. [CrossRef]

114. Gietl, J.K.; Lawrence, R.; Thorpe, A.J.; Harrison, R.M. Identification of brake wear particles and derivation of a quantitative tracer for brake dust at a major road. Atmos. Environ. 2010, 44, 141-146. [CrossRef]

115. Jeong, C.-H.; Wang, J.M.; Hilker, N.; Debosz, J.; Sofowote, U.; Su, Y.; Noble, M.; Healy, R.M.; Munoz, T.; Dabek-Zlotorzynska, E.; et al. Temporal and spatial variability of traffic-related PM2.5 sources: Comparison of exhaust and non-exhaust emissions. Atmos. Environ. 2019, 198, 55-69. [CrossRef]

116. Alves, D.D.; Riegel, R.P.; Klauck, C.R.; Ceratti, A.M.; Hansen, J.; Cansi, L.M.; Pozza, S.A.; de Quevedo, D.M.; Osório, D.M.M. Source apportionment of metallic elements in urban atmospheric particulate matter and assessment of its water-soluble fraction toxicity. Environ. Sci. Pollut. Res. 2020, 27, 12202-12214. [CrossRef] [PubMed]

117. Kwak, J.; Kim, H.; Lee, J.; Lee, S. Characterization of non-exhaust coarse and fine particles from on-road driving and laboratory measurements. Sci. Total Environ. 2013, 458-460, 273-282. [CrossRef]

118. Birmili, W.; Allen, A.G.; Bary, F.; Harrison, R.M. Trace Metal Concentrations and Water Solubility in Size-Fractionated Atmospheric Particles and Influence of Road Traffic. Environ. Sci. Technol. 2006, 40, 1144-1153. [CrossRef]

119. Valotto, G.; Zannoni, D.; Rampazzo, G.; Visin, F.; Formenton, G.; Gasparello, A. Characterization and preliminary risk assessment of road dust collected in Venice airport (Italy). J. Geochem. Explor. 2018, 190, 142-153. [CrossRef] 
120. Prakash, J.; Lohia, T.; Mandariya, A.K.; Habib, G.; Gupta, T.; Gupta, S.K. Chemical characterization and quantitativ e assessment of source-specific health risk of trace metals in PM1.0 at a road site of Delhi, India. Environ. Sci. Pollut. Res. 2018, 25, 8747-8764. [CrossRef]

121. Xue, W.; Xue, J.; Mousavi, A.; Sioutas, C.; Kleeman, M.J. Positive matrix factorization of ultrafine particle mass (PM0.1) at three sites in California. Sci. Total Environ. 2020, 715, 136902. [CrossRef]

122. Acquafredda, P. XRF technique. Phys. Sci. Rev. 2019, 4, 20180171. [CrossRef]

123. Streli, C.; Wobrauschek, P.; Kregsamer, P. X-Ray Fluorescence Spectroscopy, Applications. In Encyclopedia of Spectroscopy and Spectrometry, 3rd ed.; Lindon, J.C., Tranter, G.E., Koppenaal, D.W., Eds.; Academic Press: Oxford, UK, 2017; pp. 707-715. ISBN 978-0-12-803224-4.

124. Verma, P.C.; Ciudin, R.; Bonfanti, A.; Aswath, P.; Straffelini, G.; Gialanella, S. Role of the friction layer in the high-temperature pin-on-disc study of a brake material. Wear 2016, 346-347, 56-65. [CrossRef]

125. Alemani, M.; Gialanella, S.; Straffelini, G.; Ciudin, R.; Olofsson, U.; Perricone, G.; Metinoz, I. Dry sliding of a low steel friction material against cast iron at different loads: Characterization of the friction layer and wear debris. Wear 2017, 376-377, 1450-1459. [CrossRef]

126. Malachova, K.; Kukutschova, J.; Rybkova, Z.; Sezimova, H.; Placha, D.; Cabanova, K.; Filip, P. Toxicity and mutagenicity of low-metallic automotive brake pad materials. Ecotoxicol. Environ. Saf. 2016, 131, 37-44. [CrossRef] [PubMed]

127. Lutterotti, L.; Matthies, S.; Wenk, H.-R.; Schultz, A.S.; Richardson, J.W. Combined texture and structure analysis of deformed limestone from time-of-flight neutron diffraction spectra. J. Appl. Phys. 1997, 81, 594-600. [CrossRef]

128. Rietveld, H.M. A profile refinement method for nuclear and magnetic structures. J. Appl. Crystallogr. 1969, 2, 65-71. [CrossRef]

129. Menapace, C.; Leonardi, M.; Secchi, M.; Bonfanti, A.; Gialanella, S.; Straffelini, G. Thermal behavior of a phenolic resin for brake pad manufacturing. J. Therm. Anal. Calorim. 2019, 137, 759-766. [CrossRef]

130. Wei, L.; Choy, Y.S.; Cheung, C.S. A study of brake contact pairs under different friction conditions with respect to characteristics of brake pad surfaces. Tribol. Int. 2019, 138, 99-110. [CrossRef]

131. Matějka, V.; Metinöz, I.; Wahlström, J.; Alemani, M.; Perricone, G. On the running-in of brake pads and discs for dyno bench tests. Tribol. Int. 2017, 115, 424-431. [CrossRef]

132. Österle, W.; Prietzel, C.; Kloß, H.; Dmitriev, A.I. On the role of copper in brake friction materials. Tribol. Int. 2010, 43, 2317-2326. [CrossRef]

133. Eriksson, M.; Bergman, F.; Jacobson, S. On the nature of tribological contact in automotive brakes. Wear 2002, 252, 26-36. [CrossRef]

134. Österle, W.; Dmitriev, A.I. Functionality of conventional brake friction materials-Perceptions from findings observed at different length scales. Wear 2011, 271, 2198-2207. [CrossRef]

135. Cho, M.H.; Cho, K.H.; Kim, S.J.; Kim, D.H.; Jang, H. The Role of Transfer Layers on Friction Characteristics in the Sliding Interface between Friction Materials against Gray Iron Brake Disks. Tribol. Lett. 2005, 20, 101-108. [CrossRef]

136. Kukutschová, J.; Moravec, P.; Tomášek, V.; Matějka, V.; Smolík, J.; Schwarz, J.; Seidlerová, J.; Šafářová, K.; Filip, P. On airborne nano/micro-sized wear particles released from low-metallic automotive brakes. Environ. Pollut. 2011, 159, 998-1006. [CrossRef] [PubMed]

137. Österle, W.; Prietzel, C.; Dmitriev, A.I. Investigation of surface film nanostructure and assessment of its impact on friction force stabilization during automotive braking. Int. J. Mater. Res. 2010, 101, 669-675. [CrossRef]

138. Österle, W.; Urban, I. Third body formation on brake pads and rotors. Tribol. Int. 2006, 39, 401-408. [CrossRef]

139. Filip, P.; Weiss, Z.; Rafaja, D. On friction layer formation in polymer matrix composite materials for brake applications. Wear 2002, 252, 189-198. [CrossRef]

140. Österle, W.; Kloß, H.; Urban, I.; Dmitriev, A.I. Towards a better understanding of brake friction materials. Wear 2007, 263, 1189-1201. [CrossRef]

141. Österle, W.; Urban, I. Friction layers and friction films on PMC brake pads. Wear 2004, 257, 215-226. [CrossRef]

142. Österle, W.; Dörfel, I.; Prietzel, C.; Rooch, H.; Cristol-Bulthé, A.-L.; Degallaix, G.; Desplanques, Y. A comprehensive microscopic study of third body formation at the interface between a brake pad and brake disc during the final stage of a pin-on-disc test. Wear 2009, 267, 781-788. [CrossRef]

143. Österle, W.; Griepentrog, M.; Gross, T.; Urban, I. Chemical and microstructural changes induced by friction and wear of brakes. Wear 2001, 251, 1469-1476. [CrossRef] 
144. Hinrichs, R.; Vasconcellos, M.A.Z.; Österle, W.; Prietzel, C. A TEM snapshot of magnetite formation in brakes: The role of the disc's cast iron graphite lamellae in third body formation. Wear 2011, 270, 365-370. [CrossRef]

145. Asadabad, M.A.; Eskandari, M.J. Transmission Electron Microscopy as Best Technique for Characterization in Nanotechnology. Synth. React. Inorg. Met.-Org. Nano-Met. Chem. 2015, 45, 323-326. [CrossRef]

146. Anjum, D.H. Characterization of nanomaterials with transmission electron microscopy. IOP Conf. Ser. Mater. Sci. Eng. 2016, 146, 012001. [CrossRef]

147. Zhao, J.; Lewinski, N.; Riediker, M. Physico-Chemical Characterization and Oxidative Reactivity Evaluation of Aged Brake Wear Particles. Aerosol Sci. Technol. 2015, 49, 65-74. [CrossRef]

148. Serafini, A.; Lutterotti, L.; Gross, S.; Gialanella, S. Characterization of nanograined powder samples using the Rietveld method applied to electron diffraction ring patterns. Powder Diffr. 2017, 32, S63-S68. [CrossRef]

149. Perricone, G.; Matějka, V.; Alemani, M.; Wahlström, J.; Olofsson, U. A Test Stand Study on the Volatile Emissions of a Passenger Car Brake Assembly. Atmosphere 2019, 10, 263. [CrossRef]

150. Nosko, O.; Vanhanen, J.; Olofsson, U. Emission of 1.3-10 nm airborne particles from brake materials. Aerosol Sci. Technol. 2017, 51, 91-96. [CrossRef]

151. Alemani, M.; Olofsson, U.; Perricone, G.; Söderberg, A.; Wahlström, J.; Ciotti, A. A Study on the Load Level Influence on Particulate Matter Emissions From the Sliding Contact Between a Low Steel Friction Material and Cast Iron. In Proceedings of the Eurobrake 2015, Dredsen, Germany, 4-6 May 2015.

152. Ramousse, S.; Høj, J.W.; Sørensen, O.T. Thermal characterisation of brake pads. J. Therm. Anal. Calorim. 2001, 64, 933-943. [CrossRef]

153. Bijwe, J.; Majumdar, N.; Satapathy, B.K. Influence of modified phenolic resins on the fade and recovery behavior of friction materials. Wear 2005, 259, 1068-1078. [CrossRef]

154. Ingo, G.M.; D’Uffizi, M.; Falso, G.; Bultrini, G.; Padeletti, G. Thermal and microchemical investigation of automotive brake pad wear residues. Thermochim. Acta 2004, 418, 61-68. [CrossRef]

155. Eddoumy, F.; Kasem, H.; Dhieb, H.; Buijnsters, J.G.; Dufrenoy, P.; Celis, J.-P.; Desplanques, Y. Role of constituents of friction materials on their sliding behavior between room temperature and $400{ }^{\circ} \mathrm{C}$. Mater. Des. (1980-2015) 2015, 65, 179-186. [CrossRef]

156. Peikertova, P.; Vaculik, M.; Filip, P.; Kukutschova, J. Raman Microspectroscopy as a Tool for Characterization of Brake Wear Debris. In Proceedings of the Nanocon 2012 4th International Conference, Brno, Czech Republic, 23-25 October 2012; pp. 842-846.

157. Peikertová, P.; Kukutschová, J.; Vávra, I.; Matějka, V.; Životský, O.; Vaculík, M.; Lee, P.W.; Filip, P. Water suspended nanosized particles released from nonairborne brake wear debris. Wear 2013, 306, 89-96. [CrossRef]

158. Perrenoud, A.; Gasser, M.; Rothen-Rutishauser, B.; Gehr, P.; Riediker, M. Characterisation of nanoparticles resulting from different braking behaviours. Int. J. Biomed. Nanosci. Nanotechnol. 2010, 1, 17-33. [CrossRef]

159. Gasser, M.; Riediker, M.; Mueller, L.; Perrenoud, A.; Blank, F.; Gehr, P.; Rothen-Rutishauser, B. Toxic effects of brake wear particles on epithelial lung cells in vitro. Part. Fibre Toxicol. 2009, 6, 30. [CrossRef]

160. Plachá, D.; Peikertova, P.; Kukutschova, J.; Lee, P.W.; Čabanová, K.; Karas, J.; Kuchařová, J.; Filip, P. Identification of Organic Compounds Released from Low-Metallic Automotive Model Brake Pad and its Non-Airborne Wear Particles. SAE Int. J. Mater. Manuf. 2016, 9, 123-132. [CrossRef]

161. Eriksson, M.; Jacobson, S. Tribological surfaces of organic brake pads. Tribol. Int. 2000, 33, 817-827. [CrossRef]

Publisher's Note: MDPI stays neutral with regard to jurisdictional claims in published maps and institutional affiliations.

(C) 2020 by the authors. Licensee MDPI, Basel, Switzerland. This article is an open access article distributed under the terms and conditions of the Creative Commons Attribution (CC BY) license (http://creativecommons.org/licenses/by/4.0/). 